\title{
Symbolic and functional brand effects in the hedonic assessment of South African wines
}

\author{
D. Priilaid* \\ School of Management Studies, University of Cape Town, \\ Private Bag, Rondebosch 7700, Republic of South Africa \\ David.Priilaid@uct.ac.za \\ P. van Rensburg \\ School of Management Studies, University of Cape Town, \\ Private Bag, Rondebosch 7700, Republic of South Africa
}

Received March 2010

\begin{abstract}
Proceeding from work that identifies price as an extrinsic cue that can mediate between a wine's perceived and intrinsic merit, the brand construct is presented as an additional potential mediator. Here we define (1) "functional" brands as representations of intrinsic (blind-tasted) quality, and (2) "symbolic" brands (as proxied by the difference between a wine's intrinsic and extrinsic (sighted-tasted) evaluations) as placebos. Using a database of 8225 paired tastings (sighted and blind) of popular South African cultivars sampled over an eight year period, we control for contending price and vintage cues to identify the scale, character and distribution of a given set of functional and symbolic brand effects. Respectively these are identified as occurring in the frequency of roughly two-to-one. The 30 strongest of each are tabled. A subset of brands that present simultaneously as both functional and symbolic is further scrutinised. This set decomposes into two distinctive clusters located approximately one standard deviation left and right of the broader intrinsic mean. The smaller Zone of Symbolic Values is characterised by weak intrinsics and strong positive placebos. The second, larger Zone of Functional Values presents the opposite: negative placebos and strong functional intrinsics. Through the calibration and scaling of these brand-effects, wine producers can better understand what proportion of their product's sight-driven appeal can ably be ascribed to a brand's placebo as opposed to the underlying quality. Consequently their marketers may now more knowledgably amplify (or, where appropriate, down-play) the label-cue and adjust their wine marketing communication accordingly.
\end{abstract}

*To whom all correspondence should be addressed.

\section{Introduction}

A corpse in a doorway dried to leather. Grimacing at the day. He pulled the boy closer. Just remember that the things you put in your head are there forever, he said. You might want to think about that.

You forget some things don't you?

Yes. You forget what you want to remember and you remember what you want to forget.

Cormac McCarthy, The Road (2006, 10).

Extrinsic cues play a critical role in the sale of sensory products such as wine since they enable the increase of hedonic pleasure without additional effort or expenditure. From the consumer perspective, these cues have been shown to be the principal evaluative criteria used by consumers during the buying process (see Halstead, 2002; Spawton, 1991). This is especially true since wine consumers are characterised by low levels of predetermination and, thus, typically carry out their decision to purchase only when in store (Seghieri, Casini \& Torrisi, 2007). The literature identifies a number of extrinsic cues that can mediate a wine's intrinsic merit, the most important of these being price (see inter-alia Plassmann, O’Doherty, Shiv \& Rangel, 2008). In this study the brand construct is presented as an additional potential mediator.

Wine quality evaluations can be tasted blind or sighted. Unlike their sighted equivalents, blind tastings are devoid of extrinsic cue bias and are generally held to be fair representations of a wine's intrinsic quality. In this study we define "functional" brands as those which present with predictably consistent assessments of intrinsic quality. By contrast, we define "symbolic" brands (as proxied by a predictably consistent difference between a wine's intrinsic and extrinsic merit), as placebos. This sighted-to-blind differential equates with the "value-added" view of brand equity (inter-alia, see Kamakura \& Russell, 1993; Keller, 1993; Erdem \& Swait, 1998) and is commonly employed when a brand's utility cannot adequately be explained by the functional attributes at hand. This construct aligns well with Keller's (1993: 2) definition of consumer-led brand equity which he cites as the "consumers' reaction to an element of the marketing mix for the brand "in comparison" with their reaction to the same marketing mix element attributed to a 
fictitiously named or unnamed version of the product or service".

The above two constructs accord with the work of Bhat and Reddy (1998) who constitute symbolism and functionalism as two separate brand components. Significantly they note that, in the mind of the consumer, it is possible for a brand to register with both symbolic and functional appeal. We thus observe that by definition, brands can present simultaneously as markers of functional quality and of symbolic appeal: functional in the sense that they present with predictable intrinsic merit; symbolic in that they present with predictable sighted-to-blind differentials - in other words, placebos.

In this study a database of 8225 blind and sighted wine assessments (as manifest in star ratings) is collated so as to observe, while controlling for contending vintage and price cues, the extent to which functional and symbolic brandeffects can be identified, mapped out and interpreted. Potential terroir effects are not considered in this analysis since too many wines within the dataset were considered insufficiently terroir-contingent. (As per the work of Priilaid (2007), within South Africa, terroir cue-effects can merit assessment only if the wines in question emanate from a ward, being the smallest wine-producing land-unit with ecological features sufficiently distinctive to produce the signature of locale that we deem "terroir" (Carey, 2005). In the main, wines featured on this database failed to satisfy this ward-of-origin specification, many being sourced at a wider district or even regional level; this being the case especially with beverage-type wines commonly produced at high volume.)

If we are able to calibrate and scale these brand-effects, wine producers will know what proportion of their product's sight-driven appeal can ably be ascribed to a brand's placebo as opposed to the underlying quality. Consequently their marketers may more knowledgably amplify (or, where appropriate, down-play) the label-cue, and adjust their wine marketing communication accordingly.

The paper is organised as follows. Section two reviews the literature. The dataset is introduced in section three. Section four presents, contrasts and ranks a cross-section of cultivar-specific brand-effects, both functional and symbolic. Where brands are found to be simultaneously functional and symbolic, (respectively presenting consistent intrinsic merit and placebos), their respective empirical properties are explored and mapped out. Section five concludes.

\section{Literature review}

Wine brands are observed to dominate in markets that are less inclined to employ terroir-units as markers of quality. These so-called new world territories include most of the English-speaking world as well as certain countries in South America and Asia (Robinson, 2006). The wine market in the USA is a case in point, where rapid market consolidation has enabled the top eight wine companies to capture $75 \%$ of that 20-billion-dollar per annum industry. These eight also dominate distribution and above-the-line media. This, together with a nation-wide consolidation amongst retailers and distributors, has contributed towards the downward pressure on wine prices. The remaining $25 \%$ market share is deeply divided by some 1600 smaller wine producers. As Kim and Mauborgne (2005: 25) describe it, the effect of all this is a massive "red ocean of bloody competition" (see also Taplin, 2006).

In situation in South Africa is none too different. While in 1996 there were only 295 wine cellars (Ponte \& Ewert, 2007), by 2005 this figure had almost doubled to 581 . This notwithstanding, according the national buyer of Pick ' $n$ Pay (personal communication), South Africa's leading supermarket chain responsible for some $37 \%$ of domestic supermarket wine sales, volume sales in 2006 were dominated by no more than 10 brands, operating typically in the R14 to R30 price bracket.

With respect to the context above, aside from acknowledging the new world preponderance for a few cheap commodity-type brands that compete amidst a swathe of high-price-high-quality wine brands, the literature appears mostly silent on the extent to which the brandconstruct actually remains a valid and useful marketing tool in the wine industry. Writing from an old world perspective, Robinson (2006) suggests, merely, that wine brands compete at the bottom-end of the market, serving as interpretive heuristics to uninitiated wine drinkers: "But as wine drinkers become more sophisticated, they learn to decode what initially seems the arcane language of wine names, usually by identifying the major varietals and some of the more important place-names" (Robinson, 2006: 102). Specifically within a new world context where terroir is not common currency and where a selection of wines based simply on varietal is too broad to be meaningful, Robinson's asserted primacy of this two-pronged selection strategy appears ill-conceived.

When one considers the high proportion of quality wines that jostle for attention, a case must be made for an additional suite of mid-to-high-point brands that can serve as a decision-heuristic to more discerning wine drinkers. However, while acknowledging the lower stratum of a few commodity-type wine brands, empirically derived literature on the topic of wine branding and loyalty is largely undeveloped (see Chaney, 2000; Lockshin, Rasmussen \& Cleary, 2000; Mowle \& Merrilees, 2005; Casini, Rungie \& Corsi, 2009) - or, as in the instance of the worldwide study on the extrinsic influencers of consumer wine choice (see Goodman, Lockshin, Cohen, Fensterseifer, Ma, d'Hauteville, Sirieix, Orth, Casini, Corsi, Jaeger, Danaher, Brodie, Olsen, Thatch \& Perrouty, 2008), still developing. Thus, as Mowle and Merrilees (2005: 220) observe in the main, "(d)espite the vital role that brands play in the successful marketing of wine, there appears to be a paucity of empirical research into branding in the wine industry."

In June 2007 an initial piece of South Africa wine branding research was published by WINE magazine in the form of a readership survey asking the drinking public to nominate the best winery and best emerging winery in South Arica. The response sample $(n=600)$ was deemed large enough for valid inferences, with a sample error of $2 \%$ (see McDonald et al., 
2007). The "best" winery as voted by the respondents was Vergelegen, Anglo America's flagship winery based in Somerset West, near Stellenbosch. Table 1 below also showcases the top twelve wineries cited in the poll, and includes Thelema, Rustenberg, Boekenhoutskloof and Hamilton Russell.

Table 1 also features a number of top-selling wines from the Distell group. Along with the Douglas Green Bellingham (DGB) group, Distell is South Africa's largest producerwholesaler (Ponte \& Ewert, 2007), and is currently listed on the Johannesburg Stock Exchange. (DGB produce commodity type wines under labels such as Douglas Green, The Saints, Tall Horse, and St Augustine, none of which fits the (six-or-more) specification for candidate brands within the varietal subsets under scrutiny.) Included within the Distell stable are international labels Fleur du Cap, Durbanville Hills and Nederburg, with an annual case output of 180000,140000 , and a staggering 1,1 million, respectively. The question remains: all things held equal, how do the above-mentioned wineries perform when evaluated for potential brand effects?

Table 1: Prominent South African wineries as per (1) a June 2007 WINE magazine survey and (2) Distell's listed wine brands - their annual case output and their relative significance within the dataset. (sources: Boom, 2006; Van Zyl, 2007; Wine, 2007; and the 2007 financials of the JSE listed Distell liquor group.) Distell wines with an (I) denote an international profile

\begin{tabular}{|c|c|c|c|c|}
\hline & Winery & $\begin{array}{l}\% \text { voted by } \\
\text { Wine readers }\end{array}$ & $\begin{array}{l}\text { Cases per } \\
\text { annum }\end{array}$ & $\begin{array}{c}\text { Frequency of candidate brands featured in } \\
\text { this dataset by varietal }\end{array}$ \\
\hline \multirow{8}{*}{$\begin{array}{l}\text { South Africa's } \\
\text { “best” winery in } \\
2007 \text { as voted by } \\
\text { WINE magazine } \\
\text { readers }\end{array}$} & Vergelegen & $37 \%$ & $47000 \mathrm{cs}$ & $\begin{array}{l}\text { cabernet (6), shiraz (7), red blends (12), } \\
\text { chardonnay (15), sauvignon blanc (14) white } \\
\text { blends (6). }\end{array}$ \\
\hline & Thelema & $14 \%$ & $30000 \mathrm{cs}$ & $\begin{array}{l}\text { cabernet (10), merlot (15), shiraz (8), } \\
\text { chardonnay (13), sauvignon blanc (12). }\end{array}$ \\
\hline & Rustenburg & $11 \%$ & $130000 \mathrm{cs}$ & Cabernet (7), red blends (7), chardonnay (12). \\
\hline & Boekenhoutskloof & $10 \%$ & $120000 \mathrm{cs}$ & Cabernet (8), shiraz (7), red blends (8). \\
\hline & Hamilton Russell & $10 \%$ & $13500 \mathrm{cs}$ & pinot noir (9), chardonnay (8) \\
\hline & Kanonkop & Below $10 \%$ & $50000 \mathrm{cs}$ & cabernet (6), pinotage (8), red blend (13). \\
\hline & Kanu & Below $10 \%$ & $38000 \mathrm{cs}$ & $\begin{array}{l}\text { merlot (8), shiraz (9), red blend (11), } \\
\text { chardonnay ( } 8) \text {, chenin blanc(13), sauvignon } \\
\text { blanc (10). }\end{array}$ \\
\hline & Jordan & Below $10 \%$ & $65000 \mathrm{cs}$ & $\begin{array}{l}\text { cabernet (8), merlot (6), red blends (10), } \\
\text { chardonnay (13), chenin blanc (6), sauvignon } \\
\text { blanc (13). }\end{array}$ \\
\hline \multirow{6}{*}{$\begin{array}{l}\text { South Africa's "best } \\
\text { emerging" winery in } \\
2007 \text { as voted by } \\
\text { WINE magazine } \\
\text { readers }\end{array}$} & Cape Point Vineyards & $29 \%$ & $7000 \mathrm{cs}$ & sauvignon blanc (13). \\
\hline & Tokara & $24 \%$ & $50000 \mathrm{cs}$ & sauvignon blanc (11). \\
\hline & De Toren & $18 \%$ & $7000 \mathrm{cs}$ & red blends (10). \\
\hline & Ernie Els & $9 \%$ & $45000 \mathrm{cs}$ & red blends $(8)$ \\
\hline & Sadie Family & $7 \%$ & $900 \mathrm{cs}$ & shiraz (7). \\
\hline & Raka & Below 7\% & $15000 \mathrm{cs}$ & red blends (9). \\
\hline \multirow{9}{*}{$\begin{array}{l}\text { Distell wines } \\
\text { featured in this } \\
\text { dataset }\end{array}$} & Allesverloren & $\mathrm{n} / \mathrm{a}$ & $50000 \mathrm{cs}$ & cabernets (6), shiraz (6). \\
\hline & Alto & $\mathrm{n} / \mathrm{a}$ & $25000 \mathrm{cs}$ & red blends $(7)$ \\
\hline & Chateau Libertas & $\mathrm{n} / \mathrm{a}$ & Not cited & red blends (4) (did not qualify; < 6). \\
\hline & Drosdy Hof & $\mathrm{n} / \mathrm{a}$ & Not cited & Nil. \\
\hline & Durbanville Hills (I) & $\mathrm{n} / \mathrm{a}$ & $140000 \mathrm{cs}$ & merlot (10), shiraz (6), sauvignon blanc (11). \\
\hline & Fleur du Cap (I) & $\mathrm{n} / \mathrm{a}$ & $180000 \mathrm{cs}$ & $\begin{array}{l}\text { cabernet (17), merlot (15), shiraz (17), } \\
\text { chardonnay (13), sauvignon blanc (13). }\end{array}$ \\
\hline & Le Bonheur & $\mathrm{n} / \mathrm{a}$ & $37000 \mathrm{cs}$ & $\begin{array}{l}\text { red blends (6), chardonnay (6), sauvignon blanc } \\
\text { (6). }\end{array}$ \\
\hline & Lomond & $\mathrm{n} / \mathrm{a}$ & $300 \mathrm{cs}$ & sauvignon blanc $(7)$ \\
\hline & Nederburg (I) & $\mathrm{n} / \mathrm{a}$ & $1100000 \mathrm{cs}$ & $\begin{array}{l}\text { cabernet (12), pinotage (6), shiraz (7), red } \\
\text { blends (11), chardonnay (9), sauvignon blanc } \\
\text { (15). }\end{array}$ \\
\hline \multirow[t]{6}{*}{$\begin{array}{c}\text { as per } 2007 \\
\text { financial results }\end{array}$} & Neethlingshof & $\mathrm{n} / \mathrm{a}$ & $100000 \mathrm{cs}$ & $\begin{array}{l}\text { cabernet (6), red blends (8), chardonnay (8), } \\
\text { sauvignon blanc (6). }\end{array}$ \\
\hline & Plasir de Merle & $\mathrm{n} / \mathrm{a}$ & $55000 \mathrm{cs}$ & merlot (8), chardonnay (6). \\
\hline & Stellenzicht & $\mathrm{n} / \mathrm{a}$ & $120000 \mathrm{cs}$ & $\begin{array}{l}\text { pinotage (7), shiraz (12), red blends (9), } \\
\text { chardonnay (7), sauvignon blanc ( } 8) .\end{array}$ \\
\hline & Tassenberg & $\mathrm{n} / \mathrm{a}$ & Not cited & red blends $(2)($ did not qualify; $<6)$ \\
\hline & Uitkyk & $\mathrm{n} / \mathrm{a}$ & $73000 \mathrm{cs}$ & chardonnay (6), sauvignon blanc (8). \\
\hline & Zonnebloem & $\mathrm{n} / \mathrm{a}$ & $220000 \mathrm{cs}$ & pinotage $(6)$, red blend $(7)$ \\
\hline
\end{tabular}


At a conceptual level Getz (2000), Lockshin, Rasmussen and Cleary (2000) and Mowle and Merrilees (2005) appear as the only authors dealing with a brand's functional and symbolic components within the wine industry. All note that successful branding strategies require the integration of both functional and symbolic components. Mowle and Merrilees (2005: 255) go further to posit an interdependency between these two components: "( $f$ )or the product-driven wineries, the functional qualities of product quality were leveraged to develop the symbolic and emotional values of prestige and exclusivity. In contrast, the marketing-driven branding wineries placed more emphasis on the end-point of emotional value and used the cellar door experience, promotions and extended product range to build the symbolic properties of the brand image".

While the conceptual contribution of these authors is important, certain questions remain unanswered. For example, precisely which wine brands (if any) offer little or no intrinsic merit, yet still enable a degree of sighted enjoyment? More so, when faced with a multitude of competing brands, to what extent will Brand A drive one's sighted appreciation of a wine when compared to Brand B? Could an alternate set of "negative" "non-brands" also exist antithetically to the orthodox view that by tent, all brands should deliver added pleasantness to the sampling experience? Such questions, as they relate to the weighted performance of one brand relative to another, are clearly important, and here the underlying issue of tasting procedure and the all-too-common disparity between sighted and blind versions of wine quality provides a useful point of entry.

Recent research pieces have argued that this disparity can, in part, be explained by certain extrinsic cues which serve to obfuscate a product's intrinsic merit. These works have moved on to theorise how, in our sighted appreciation of hedonic products like wine; we are deleteriously distracted by various extrinsic cues, and have conjectured that this phenomenon implies a neurological impairment of the brain's field of judgement, rendering it incapable of explain the true source of quality. In late 2005, a specially published edition of the Journal of Marketing Research speculated that this neurological quirk has broader levels of expression - most commonly observed in the placebo effect. So doing this edition noted the apparent efficacy of the price cue as an important (though) unconscious mediator of experienced pleasure (see principally Shiv, Carmon and Ariely (2005), but also Borsook and Becerra (2005), Rao (2005), Berns (2005), and Irmak, Block and Fitzsimons (2005)). A further paper notifying terroir-effects in an analysis of blind and sighted quality assessments of South African varietal wines (see Priilaid (2007)) added additional force to the view that the placebo effect was a general human phenomenon.

In January 2008, Plassmann and colleagues published a wine-based study observing the neurological response to changes in price whilst holding quality constant. Using functional Magnetic Resonance Imaging (fMRI) scanning techniques on 20 subjects, the results confirmed what previous studies had long anticipated: that "increasing the price of a wine increases subjective reports of flavour pleasantness as well as blood-oxygen-level-dependent activity in the medial-orbitofrontal cortex, an area widely thought to encode for experienced pleasantness during experimental tasks" (Plassmann et al., 2008: 1050); and thus that neurologically, price is perceived as a better measure of quality than quality itself.

On the basis of this existing body research, we can reasonably hypothesise that these same effects will occur when replacing the price cue with one of brand. Using Pepsi and Coke in blind and sighted taste-tests, a study published in 2004 (see McClure, Tomlin, Cypert, Montague \& Montague, 2004), reported neural responses correlating with brand choice. Colas preferred when tasting blind showed no correlation to the brand generally preferred by the subjects when shopping. However, Coke was preferred in the sighted tests - arguably because of its dominance as a brand. As one of the co-authors reported later, "the Coke brand has a flavour, or at least was a major contributor to the experienced flavour. Not so for the Pepsi brand" (Montague, 2006: 209). In the two styles of tasting, different regions of the brain showed different levels of activity. In the blind sampling the ventral putamen region of the brain was activated; in the sighted, the ventromedial prefrontal cortex. While the former region functions as the locus of sensation and reward, the latter serves as the processor of memory and judgement. The study implied a neurological idiosyncrasy: that when tasting sighted, the brain overlooks intrinsic merit, preferring rather to focus on familiar asserted cues. (See also Kawabata and Zeki (2004) for analogous studies observing the neural response to artwork).

Using the dopamine gating hypothesis, a neurological theory explaining how the brain assigns value to hedonic stimulation, Montague (2006) speculates that the seeming preference for readily accessible cues is an evolutionary adaptation that allows the brain to reach states of either pain-avoidance or pleasure more efficiently. In such a fashion, he argues that, historically, primitive hominoids would survive better if listening out for the tell-tale portents of death (a snapping twig) rather than for death itself (the arrival of a sabre-tooth tiger) - then it would be too late. Successfully reproducing individuals would consequently carry the genetic bias for the processing of enabling cues rather than processing the direct experience itself. We conjecture that this instinctual predisposition for such cues continues to play out within contemporary commercial jungles where marketing actions such as price, area-oforigin and brand serve as teaching signals, similar to the snapping twigs of old. (See also Erk et al. (2002), and Plassmann et al. (2008). Therefore, if we can construe a brand as "a promise to deliver", then it is upon this promise that the brain's dopamine levels will tend to rise in anticipation of the delivery itself. Given this evolutionary context, the extent of reported consumer vulnerability to the market cues that assail us daily is perhaps not surprising. Still there is much we do not fully understand, and in the light of these neurobiological considerations, it is worthwhile considering how certain brands (might) configure as placebo-like proxies of underlying quality, and why. 
As a point of departure, we deploy Mowle and Merrilees's (2005: 224) work on functional and symbolic strategies for wine branding. These authors suggest that brands configure around two generic strategies, each an asymmetrical blend of functional and symbolic values. Respectively, these strategies decompose into two zones: the zone of symbolic values, and the zone of functional values.

The functional / symbolic distinction employed by Mowle \& Merrilees dovetails with an additional strand of marketing research that seeks to interpret the interplay between utilitarian (needs driven) and luxuriant hedonic (wants driven) product benefits. (See Oliver, 1997; Bagozzi, Gopinath \& Nyer, 1999; Rust \& Oliver, 2000; Kivetz \& Simonson, 2002a and 2002b; Chernev, 2004; Chitturi, Raghunathan \& Mahajan, 2007 and 2008; inter-alia.) While not explicitly incorporating any theory of branding or evolutionary psychology, this body of research also lays bare the different goals functional and symbolic benefits help attain. Accordingly functional (or utilitarian, instrumental or practical) goals are strongly linked with "prevention" emotions associated with pain avoidance - and align with the basic wants. Conversely symbolic (or aesthetic, hedonic or experiential) goals link up with "promotion" emotions associated with the attainment of pleasure - and thus coincide with wants. Within this body of literature there seems strong agreement that customers consider "prevention" (pain avoidance) emotions more fundamentally important than the "promotion" (pleasure attainment) emotions - and thus hold that consumers will attach greater significance to the functional (versus symbolic) dimension, unless they believe they have attained the right to treat themselves (Kivetz \& Simonson, 2002a).

While the vocabulary differentially employed by the brand and product-benefit theorists working within the wine and non-wine domains is in certain respects different ${ }^{1}-$ throughout these domains of enquiry there appears to be uncontested agreement on the Mowle \& Merrilees (2005) two-type functional / symbolic typology.

In this particular study, we extend the two-type typology by suggesting (1) that brands can be seen to perform relative to two distinct axes: the blind and the sighted versions of a wine's quality and (2) that symbolic brands accrue as placebo effects. The extent of this elaboration is depicted graphically in Figure 1. On the blind axis we consider how a brand can deliver consistent intrinsic quality by virtue of its pedigree. Blind tastings are hence the appropriate vehicle to determine whether this is so - and if so to what extent. As already noted, we have defined wineries that produce statistically consistent hedonic quality as functional brands. (The asserted primacy of credible teaching signals (such as

\footnotetext{
${ }^{1}$ By way of example, in the product-benefit literature (see for example Chitturi, Raghunathan \& Mahajan, 2008) the "symbolic versus functional" brand-distinction employed in this paper would be described rather as the "bedonic versus utilitarian" distinction. Moreover, while in brand theory the term "functional' is used to describe brands with high blind ratings; when applied more generally to foods it may equally denote health improving characteristics such as bacteria in yoghurt. Equally, while the wine literature uses the term "bedonic" assessment to describe a winequality assessment derived from a human (as opposed to a machinebased) assessment, readers in the product-benefit school would associate this term with symbolic or aesthetic attributes.
}

consistent intrinsic quality) in the formation of functional brands also aligns well with brand signalling theory (see Erdem \& Swait (1998).) This theory sees brands as signalling phenomena used by consumers to improve purchase decisions within contexts of imperfect information, and forms part of a broader stream of research based on information economics, though appearing void of evolutionary considerations.)

By contrast, the sighted-minus-blind axis (see Figure I again) provides us with an alternate means of assessing whether a winery is producing the quality it purports to. Since we know that sighted tastings are likely to be confounded by the prevalence of extrinsic cues, the empirical difference between blind and sighted assessment scores enables us to establish whether a particular wine delivers an additional level of pleasure over and above (or possibly below) its intrinsic quality. This "intangible benefit" view of brand equity is well entrenched within the literature (inter-alia, see Keller (1993) and Erdem and Swait, (1998)), and enables us to interpret wines that, over time, produce a statistically consistent difference between blind and sighted styles of assessment as placebo effects. By our definition these placebo effects constitute symbolic brands, and, depending on the relative strength of each placebo, presume a diminished degree of underlying utility.

By way of example, consider a wine in Area 1 of Figure I with a low blind score and a large positive sighted-to-blind tasting differential that implies a strong placebo effect. Unlike producers of "plonk for plonk's sake" wine producers operating somewhere in or about Area 2, such a winery would produce low-cost wines at a significant markup aimed at a segment of undemanding consumers who are satisfied with the wine's merit based solely on sighted tasting. This type of winery would trade on the high-volume commodity-type symbolic values that dominate the middleto-lower end of the price spectrum - hence their location in the notional "Zone of Symbolic Values" (in Figure 1). For the wine producer in this particular zone, two important objectives exist: (1) maintaining vinous standards within a constraining cost structure while (2) at the same time primping available extrinsic cues so as to suggest to customers that they are getting more than they actually are. As Robinson (2006: 102) notes dryly, "a high proportion of all wine drinkers were introduced to wine through brands, and it is to the credit of those brand owners most dedicated to maintaining standards whenever the introduction was a happy one." 


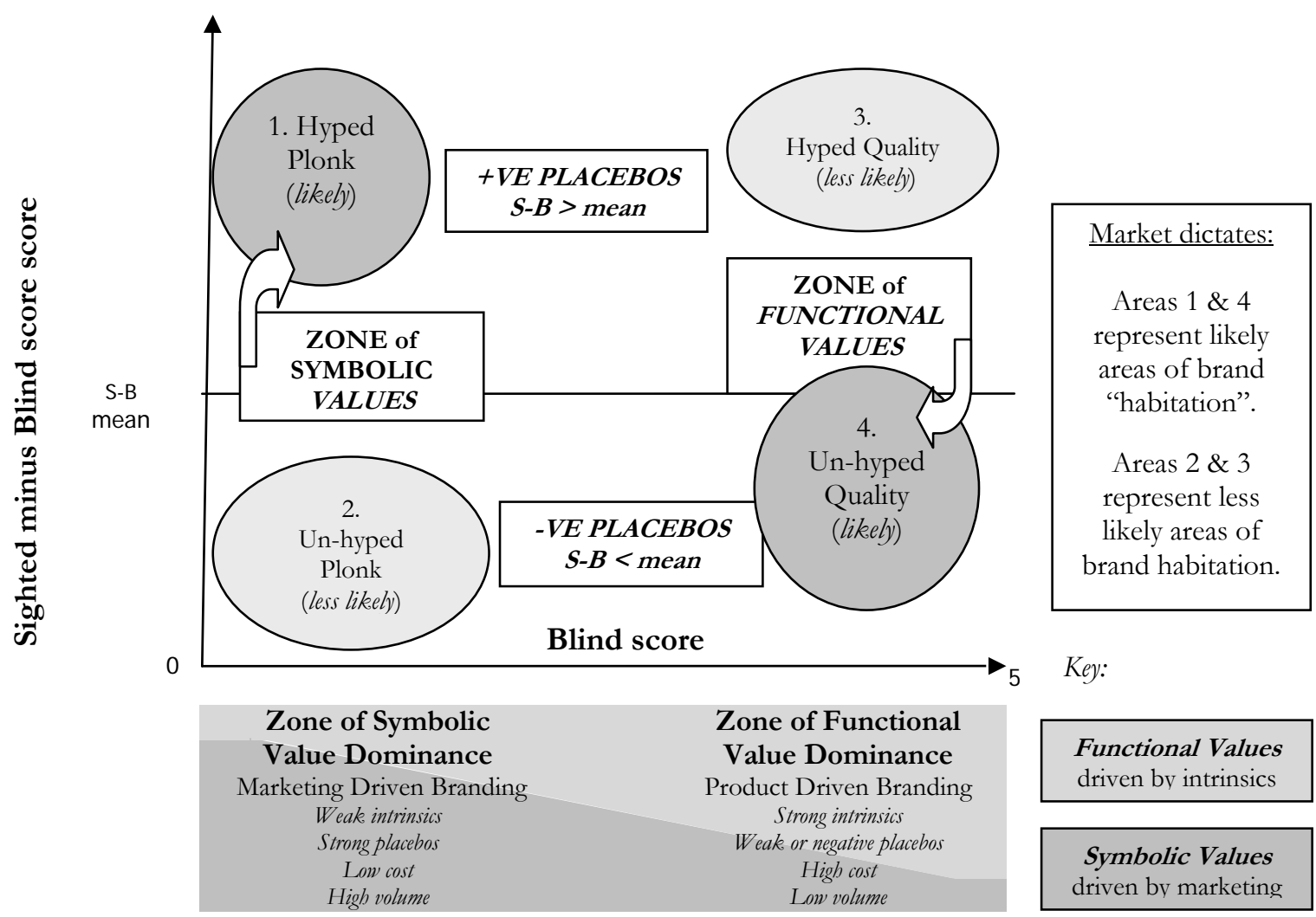

Figure 1: Proposed area of potential placebo-brand habitation: a region of brands spanning a continuum of intrinsic hedonic quality (as proxied by the blind wine score). Notionally placebo distribution should align with market realities: around the mean of blind scores; thinning out at the tails. The area of low blind scores (to the left) can attract placebos either as (1) "Hyped Plonk" (with positive placebos) or (2) as "Un-hyped Plonk" (with negative placebos). Areas of high blind scores (to the right) can attract placebos either as (3) "Hyped Quality" (with positive placebos) or (4) "Un-hyped Quality" (with negative placebos). Market realities suggest lesser-shaded areas 2 and 3 are unfeasible. Thus area 1 is the likely domain of marketing driven branding: the Zone of Symbolic Values (see Bhat and Reddy (1998) and Mowle and Merrilees (2005)). Conversely, area 4 with high blind scores (to the right), should attract small or negative placebos. This is the domain of product driven branding: the Zone of Functional Values.

By contrast, a winery consistently evincing a marginal (to possibly even a negative) (symbolic) sighted-to-blind differential coupled with a high (functional) intrinsic score (see Areas 4 and 3 in Figure 1) would serve more discriminating consumers seeking out wines of genuine merit. A brand such as this would conform to a high-cost low-volume profile, and would carry a high proportion of functional values; hence its location in the "Zone of Functional Values" as depicted in Figure 1. In order to make up on revenue lost due to the smaller volumes, we can hypothesise that such wines would carry a significant markup operating at the upper end of the price spectrum. Referring presumably to this subspecies of wine-brands, Robinson (2006: 102) observes that "it may be difficult to market branded wines in a competitive market, but it can be even more difficult to maintain the consistency of a product as variable as wine. Supplies are strictly limited to an annual batch production process. Wine cannot be manufactured to suit demand, and different vintages impose their own characteristics on the product regardless of consumer taste." Robinson's implicit point is certainly valid: hypothetically wine brands with high functional values cannot operate concurrently as brands with high symbolic values.
In the light of this functional-to-symbolic branding typology, certain questions arise. Given the hypothetical model of zones of functional and symbolic value as per Figure 1, what, in reality, is the scale, character, and distribution of a given set of functional and symbolic brand effects? Furthermore, how can we characterise the underpinning functional and symbolic values of these particular brand effects? In turn, how, too, are these distributed? While in this study answers to such questions apply specifically only to the internal constructs of the South African wine tasting professionals who generated this data, recent publications (see Siegrist and Cousin (2009) and Priilaid, Feinberg, Carter and Ross (2009)) demonstrate the extent to which public perceptions of wine quality (and hence brand) are mediated by the ratings of wine experts. We can conjecture therefore of a process of expert-to-public wine-knowledge transference whereby, for example, constructs as they emerge in studies of professional data are likely to transfer and reconfigure (though in degrees which remain uncertain) in the perceptions of the wine drinking public. In these terms any brand listing derived from this study that mirrors the public's top wine brands as depicted in Table 1 is therefore likely to add credibility to the conjecture of expert-to-public transference. 
In the context of the above, the contribution of this paper is unique therefore, in that for the first time a database of hedonic wine assessments is statistically interrogated to identify, measure and rank symbolic and functional brand effects in the context of South African wine.

\section{Description of the data}

From January 2000 to December 2007, 8225 wines were assessed blind and sighted. This data set is interrogated to establish to what extent wine brands can be invoked as (1) an explicator of intrinsic merit, as proxied by blind assessment, and also (2) the placebo, as proxied by the difference between blind and sighted assessments.

Metrics for intrinsic merit are derived from WINE magazine, which was launched in 1994, is published monthly, and tastes all of its wines blind. A four-judge panel conducts each round of assessment in the presence of a professional auditor and scores are consensus-based. These tastesessions are always based at the offices of WINE magazine, in Pinelands, Cape Town. Employing the five-star or twenty- point scoring system, superlative wines score over 18 points and receive five stars. Four-star wines are considered excellent and score between 16 and 17 points. Good to very good wines score 15 points and receive three stars, and wines deemed appealing receive 14 points or a two-star rating. 13 points are awarded to average wines, which receive one star. Zero stars are awarded to unacceptable wines. Working with the sampled wine assessment data (see Table 2), WINE magazine's mean score is 2,59 stars, with a maximum, minimum and standard deviation of 5,0 and 0,92 , respectively.

Table 2: Descriptive statistics of wine assessment scores

\begin{tabular}{c|c|c|c}
\hline & $\begin{array}{c}\text { "Sighted" } \\
\text { (Platter } \\
\text { Rating) }\end{array}$ & $\begin{array}{c}\text { “Blind" } \\
\text { (WINE Mag. } \\
\text { Rating) }\end{array}$ & $\begin{array}{c}\text { Blind } \\
\text { Minus } \\
\text { Sighted }\end{array}$ \\
\hline Minimum & 0 & 0 & $-2,5$ \\
\hline Maximum & 4,5 & 5 & 4,5 \\
\hline Mean & 3,51 & 2,59 & 0,92 \\
\hline Std. Deviation. & 0,67 & 0,92 & 0,90 \\
\hline $\mathbf{n}$ & 8225 & 8225 & 8225 \\
\hline
\end{tabular}

First published in 1981 and affectionately named after its founding editor, (John) Platter's South African Wine Guide also scores off the five-star system. In contrast to WINE magazine, the fifteen professional tasters (see van Zyl, 2007) appointed to this popular guide assess all but their five-star wines sighted. Each year, between June and August, appointed tasters divide the national allotment of wines between themselves and assessments are conducted individually on a farm-to-farm basis. The potential for personal bias in the historical tasting profile of each winery is mitigated through the annual rotation of the tasting team. While the majority of wines are awarded scores of up to four and a half stars, exceptional five-star candidate-wines are assessed blind by the team as a whole. Those wines that earn the unanimous blind-panel-endorsement of "world- class" receive the rare five-star accolade; the balance scoring four and a half stars. Out of over 6000 wines assessed for the 2008 edition of Platter, only 21 such awards were made (Van Zyl, 2007). In order to keep the blind-to-sighted distinction explicit, for the purposes of this study all Platter versions of the five-star accolade have been scored in the dataset as four-and-a-half stars - the interim score assigned to these wines before Platter's blind taste-off was conducted.

Following a process of collation and proofing, the annual John Platter tasting guide is published just before the December holiday period. A recipient of the 2007 Louis Roeder International Wine Writers' Award (inter-alia), with over 60000 copies printed annually, Platter is one of the most widely respected publications in South Africa. Writing in her Financial Times column, Robinson (2008: 4) stated recently, "I can think of no other country that has a single annual, comprehensive and definitive guide to wines produced there". Of the entire 8225 wines sampled, the mean Platter score is 3,51 stars, with a maximum, minimum and standard deviation of $4,5,0$ and 0,67 , respectively. Relative to WINE's blind assessment metrics, its higher mean and lower variability should be noted.

Blind tastings, while popular in the wine media as a form of non-biased assessment, have been critiqued due to their lack of relevance during the actual occasion of consumption (see Priilaid, 2007). This is specially so since wine consumers are known to employ extrinsic cues as a basis of wine selection (Spawton, 1991), and, only subsequently, intrinsic cues as a basis of purchase validation or otherwise. Perceived quality is hence based on a combination of intrinsic and extrinsic cues, as well as the influence of wordof-mouth recommendations (see most recently Goodman, et al., 2008).

As a composite of blind and sighted assessments, respectively WINE magazine and Platter scores constitute much of the grammar of the South Africa's wine language, and have formed the basis of several internationally published wine studies (see Van Rensburg and Priilaid, 2004; Priilaid and Van Rensburg, 2006; Priilaid, 2007).

In line with the arguments of Costanigro, et al. (2007), and as with previous studies of this nature (see Priilaid, 2007), this study holds that the extreme levels of heterogeneity that characterise the product class of wine necessitate a varietalspecific modelling approach as opposed to the conventional pooled technique. Accordingly, the entire dataset is first segmented by cultivar, whereupon the hedonic data pertaining to each cultivar are then analysed against a crosssection of brands. There are ten sub-segments in all: five red-grape varietals (cabernet sauvignon, merlot, pinotage, pinot noir, and shiraz), three white ones (chardonnay, chenin blanc, and sauvignon blanc), as well as red and white blended wines. (For purposes of simplicity, in this study the red and white blended wines will be termed varietal wines.)

The eight cultivars selected for this study constitute most of South Africa's national vineyard. Colombard (see Table 3 for details), the third most prolifically planted grape, is excluded since most of its grapes are employed in the 
production of brandy. Based on its lofty prices and the profile of some of its producers, the ever fickle though niche-like pinot noir is also included in this study. Marginal white wine equivalents such as sémillon $(1,05)$ and viognier $(0,62)$ are, however, excluded due to lack of workable data. So too are cinsaut $(2,78 \%)$, ruby cabernet $(2,61 \%)$, hanepoort $(2,60 \%)$ and Cape riesling $(1,13 \%)$, since the fruit from these cultivars is generally employed in the production of low-priced blends (Boom, 2006: 392).

Table 3: Varietals analysed for brand-cue effects. Note: white and red blends are also included in the study. (Adapted from Boom, 2006, 383-397)

\begin{tabular}{c|c|c|c}
\hline Varietals analysed & $\begin{array}{c}\text { \%of } \\
\text { national } \\
\text { vineyard }\end{array}$ & $\begin{array}{c}\text { Total } \\
\text { Hectorage }\end{array}$ & Ranking \\
\hline Chenin Blanc & $18,75 \%$ & 19053 & 1 \\
\hline Cabernet Sauvignon & $13,36 \%$ & 13572 & 2 \\
\hline Shiraz & $9,64 \%$ & 9794 & 4 \\
\hline Chardonnay & $7,80 \%$ & 7927 & 5 \\
\hline Sauvignon Blanc & $7,50 \%$ & 7661 & 6 \\
\hline Merlot & $6,83 \%$ & 6941 & 7 \\
\hline Pinotage & $6,39 \%$ & 6493 & 8 \\
\hline Pinot Noir & $0,53 \%$ & 535 & 19 \\
\hline
\end{tabular}

We identify three consumer-facing variables potentially explaining the sight-to-blind differential. These are the brand construct, price and wine vintage. A discussion of these variables follows.

\section{Wine brands}

Robinson (2006: 102) acknowledges that "the definition of a wine brand is certainly a loose one." One definition seeks the incorporation of promotional activity, coupled with elasticity in wine supply. Along with functional brands, this study takes a different consumer-facing view to argue that a symbolic brand becomes legitimate when its sighted-toblind differential can, statistically, be attributed to the wine name, while controlling for any other extrinsic cues. This then is a neurologically derived placebo effect, as the brain literally tastes the brand, all things considered. In this study, the mean average "Platter minus WINE" score (or sightedto-blind differential) is 0,92 stars, with a respective maximum, minimum and standard deviation of $4,5,-2,5$ and 0,90 .

On the basis of the rationale above, the net was thrown wide open, and candidate brands were sought out across the price spectrum. A total of 448 such brands were identified, potentially qualifying as either functional brands, symbolic brands, or both. Tables 4 and 5 present the candidate brands as they appear in each of red and white wine varietal subsets, respectively. Only brands containing six or more vintages were included for analysis. In some varietal cases, certain wineries use additional label descriptors, over and above their "umbrella" brand names (see, for example, Fleur du Cap versus Fleur du Cap Unfiltered). Where permissible under the specification, such wineries were tested both for the umbrella brand-label as well as for the specialist sub-set label (i.e. subset $n \geq 6$ ).

Table 4: Candidate brands (276 in all) as they appear in each of red wine varietal subsets. Citing frequency appears in brackets

\section{RED CULTIVARS : CANDIDATE BRANDS INCLUDED IN ANALYSIS}

\section{brands cited}

Allesverloren, Bilton, Blaauwklippen, Bon Courage, Darling Cellars, Graham Beck, Groot Constantia, Hoopenburg,

Cabernet $\quad$ Kaapzicht, Kanonkop, Laibach, Longridge, Morganhof, Neethlingshof, Porcupine Ridge, Saxenburg, Upland, Vergelegen, Viljoensdrift, Villiera, Waterford (6 times). Blue Creek, De Meye, Delheim, Diemersdal, Eikendal, Overgaauw, Rustenberg, Simonsig, Steenberg, Vergenoegd (7). Boekenhoutskloof, Boland, Flagstone, Jordan, Kleine Zalze, L'Avenir, Spier, Springfield, Stark-Conde, Stony Brook (8). Cederburg, Landskroon, Thelema (10). De Trafford (11). Le Riche and Nedeberg (12). Neil Ellis (15). Fleur du Cap (17). Bilton, Laibach, Longridge, Saxenburg, Eikendal, Jordan, Kleine Zalze, Amani, Diemesfontein, Guardian Peak,

Merlot Lanzerac, Mount Rozier, Rust en Vrede, (6 times). Veenwouden, Porcupine Ridge, Villiera, Overgaauw, Vergenoegd, Landskroon, Cordoba, Hartenberg, Meerlust, Moreson (all 7). Groot Constantia, Kaapzicht, Morganhof, Steenberg,

(36) Kanu, Plasir de Merle (8). Spier, De Trafford, Seidelberg, Woolworths (9). Durbanville Hills (10). Fleur du Cap, Thelema (15)

Altydgedacht, Bergsig, Darling Cellars, Diemersdal, Kleine Zalze, Longridge, Nederburg, Porterville, Villiera,

Pinotage $\quad$ Vriesenhof, Warwick Estate, Zonnebloem (6 times). Bellevue, De Waal, Delheim, Groot Constantia, Landskroon, Middelvlei, Rooiberg, Southern Right, Stellenzicht, Swartland Winery, Viljoensdrift (7). Beaumont, Boland, Diemesfontein, Kanonkop, Laibach, Moreson, Seidelberg (8). Bellingham, Cloof, Spier, Wildekrans, Woolworths (9). Clos Malverne, Spice Route (10). L'Avenir (12). Graham Beck (13). Beyerskloof (14). Fairview (15).Kaapzicht, Simonsig (16).

\begin{tabular}{cl} 
& Simonsig (16). \\
\hline $\begin{array}{c}\text { Pinot Noir } \\
(10)\end{array}$ & $\begin{array}{l}\text { Cabrière, Cape Chamonix, Muratie, Paul Cluver (6 times). De Trafford, Flagstone, Glen Carlou, Klein Constantia } \\
\text { (7). Hoopenburg, Hamilton Russell (9). }\end{array}$ \\
\hline \multirow{5}{*}{ Shiraz } & Allesverloren, Anthony Smook, Beaumont, Blaauwklippen, Boplaas, Cederburg, De Meye, Durbanville Hills, Genesis, \\
& Glen Carlou, Glenwood, Groot Constantia, Klein Constantia, Lievland, Neil Ellis Vineyard, Porcupine Ridge, \\
& Robertson, Rust en Vrede, Saxenburg Private Collection, Simonsvlei, Steenberg (6 times). Vergelegen, Waterford, \\
& Avondale, Boekenhoutskloof, Bovlei, Darling Cellars, Fleur du Cap, Kaapzicht, Kloovenburg, Kumkani, Landskroon, \\
& Nederburg, Nitida, Spice Route Flagship, The Sadie Family (7). Thelema, Woolworths, Havanna Hills, Kleine Zalze, \\
& Mischa (8). Boland, Delheim, Hartenberg, Kanu (9). Swartland Winery, Vergenoegd, Bellingham, Graham Beck, La \\
& Motte, Laibach, Stony Brook, Zandvliet (10). Boschendal (11). Bon Courage, Stark-Conde \& Stellenzicht (12). De \\
& Trafford (14). Simonsig (15). Fairview (23).
\end{tabular}


Asara, Beaumont, Cowlin, Jean Daneel, Klein Constantia, L'Avenir, Le Bonheur, Louisvale, Middelvlei, Rhebokskloof, Yonder Hill Winery (6 times). Alto, Backsberg, Delheim, Guardian Peak, Hartenberg, Ken Forrester, Klein Gustrouw, Moreson, Morganhof, Rust en Vrede, Rustenberg, Zonnebloem (7). Boekenhoutskloof, Cordoba, Diemesfontein, Ernie

Red Blends $\quad$ Els Wines, Graham Beck, Havanna Hills, Joostenberg, Lammershoek, Meerlust, Mont Destin, Neethlingshof, Remhoogte, Steenberg (8). Avondale, Boschendal, Diemersdal, Mont du Toit, Mulderbosch, Raka, Rupert \& Rothschild, Stellenzicht, Van Loveren, Vergenoegd, Vriesenhof (9). Blaauwklippen, Brampton, De Toren, Grangehurst, Jordan, Overgaauw, Veenwouden, Welgemeend (10). Avontuur, Buitenverwachting, Cederburg, Fairview, Groot Constantia, Kanu, Landskroon, Nederburg (11). Beyerskloof, Cloof, Eikendal, Vergelegen (12) Kanonkop, Wildekrans (13), Glen Carlou, The Goats do Roam Wine Company, Warwick Estate (14). Kaapzicht, Villiera (16). Flagstone, Simonsig (17). Clos Malverne (21). Woolworths (28).

Table 5: Candidate brands (172 in all) as they appear in each of white wine varietal subsets. Citing frequency appears in brackets.

\begin{tabular}{|c|c|}
\hline & WHITE CULTIVARS : CANDIDATE BRANDS INCLUDED IN ANALYSIS \\
\hline & brands cited \\
\hline $\begin{array}{c}\text { Chardonnay } \\
\text { (66) }\end{array}$ & $\begin{array}{l}\text { Backsberg, Boland, Dieu Donné, Hillcrest, Lanzerac, Le Bonheur, Longridge, Mont Rochelle, Paul Cluver, Plasir } \\
\text { de Merle, Rupert \& Rothschild, Uitkyk, Viljoensdrift (6 times). Asara, Beaumont, Bergsig, Bon Courage, De Meye, } \\
\text { Diemersdal, Groot Constantia, Kanu, Klein Constantia, L'Avenir, Meerlust, Newton Johnson, Saxenburg, } \\
\text { Springfield, Stellenzicht, Warwick Estate (7). Amani, Bellingham, Constantia Uitsig, Fairview, Fort Simon, } \\
\text { Hamilton Russell, Neethlingshof, Rietvallei, Simonsig, Van Loveren, Waterford (8). Avontuur, Glenwood, Graham } \\
\text { Beck, Kleine Zalze, Nederburg (9). Buitenverwachting, Delaire, Woolworths (10). Cape Chamonix, Delheim, } \\
\text { Louisvale (11). Eikendal, Rustenberg (12). Boschendal, Fleur du Cap, Glen Carlou, Jordan, Thelema (13). } \\
\text { Mulderbosch, Rhebokskloof, Neil Ellis (14). Vergelegen, Groote Post (15). Weltervrede (16). Bouchard Finlayson } \\
\text { (20). De Wetshof (21). }\end{array}$ \\
\hline $\begin{array}{l}\text { Chenin Blanc } \\
\text { (23) }\end{array}$ & $\begin{array}{l}\text { Avondale, Boschendal, Hazendal, Jean Daneel, Jordan, Perdeberg, Rijks, Spier, Viljoensdrift (6 times). Raats (7). } \\
\text { Landskroon, Mulderbosch (8). Simonsig, Villiera (9). Fort Simon, Rudera, Spice Route (10). De Trafford (11). } \\
\text { Kleine Zalze (12). Cederburg, Kanu (13). Beaumont (14). Ken Forrester (19). }\end{array}$ \\
\hline $\begin{array}{l}\text { Sauvignon - Blanc } \\
\text { (75) }\end{array}$ & $\begin{array}{l}\text { Alexanderfontein, Altydgedacht, Amani, Avondale, Avontuur, Bartho Eksteen, Bellingham, Brampton, Constantia } \\
\text { Uitsig, Du Toitskloof, Iona, Landskroon, Le Bonheur, Mooiplaas, Moreson, Moreson Pinehurst, Neethlingshof, } \\
\text { Rietvallei, Simonsig, Van Loveren, Warwick Estate, Waterford, Weltervrede (6 times). Backsberg, Boland, Bon } \\
\text { Courage, Fairview, Groot Constantia, La Motte, Laibach, L'Avenir, Lomond, Lushof, Robertson, Simonsvlei, } \\
\text { Swartland Winery (7). Bloemendal, Cederburg, Groote Post, Ken Forrester, Kleine Zalze, Neil Ellis, Southern } \\
\text { Right, Stellenzicht, Summaridge, Uitkyk, Zevenwacht (8). Cape Chamonix, Clos Malverne, Diemersdal, Graham } \\
\text { Beck, Newton Johnson, Welmoed (9). Kanu (10). Buitenverwachting, Delaire, Durbanville Hills, Klein Constantia, } \\
\text { Kumkani, Mulderbosch, Nitida, Spier, Tokara (11). Thelema (12). Cape Point Vineyards (13). Jordan, Vergelegen } \\
\text { (14). Nederburg (15). Boschendal, Springfield, Villiera (16). Fleur du Cap, Woolworths (17). Flagstone, Steenberg } \\
\text { (18). }\end{array}$ \\
\hline $\begin{array}{l}\text { White Blends } \\
(8)\end{array}$ & $\begin{array}{l}\text { Blaauwklippen, Bon Courage, Flagstone, Van Loveren, Vergelegen, Zevenwacht (6 times). Rhebokskloof (7). } \\
\text { Woolworths (12). }\end{array}$ \\
\hline
\end{tabular}

\section{Price and vintage}

The database also includes the variables' price and vintage, and these are used as controls in the analysis of blind assessments and blind-to-sighted differentials (see Tables 6 and 7 below). Data for both were sourced from various editions of WINE.

Brand-label aside, price is possibly the most important extrinsic cue appearing on each wine bottle. Studies have shown that this cue can confound one's appreciation of a wine's intrinsic merit (see Priilaid, 2006; Plassmann et al., 2008), and here we assume that it has the same effect on the sighted-to-blind differential. Cellar door prices are reported and are inflation-adjusted to those recorded in 2007; the inflation index derived by calculating the average price of a bottle of wine on a year-by-year basis.
In this analysis wine vintages span the years 1995 to 2007. 47 "non-vintage" wines are also included in the dataset. Statistics pertaining to the price and vintage cues are tabled below. By controlling for these, this paper seeks to explore the impact of a wine's label as it occurs both in blind scores and in the sighted-to-blind quality differential.

Table 8 presents the correlation matrix of ordinal variables across the entire dataset. The sighted-to-blind differential correlates most strongly (and negatively) with blind assessments (-0,73); suggesting, by construction, the occurrence of higher differentials with lower intrinsic scores. Again by construction sighted ratings also correlate with the differential, although positively, and at a lesser level $(0,34)$. Surprisingly, perhaps, price does little to explain the pooled sighted-to-blind differential. The correlation $(0,04)$ is trivial. 
Table 6: Descriptive statistics pertaining to price $(n=8225)$

\begin{tabular}{|c|c|c|c|c|}
\hline Price Segment & Number & $\begin{array}{c}\text { Percentage } \\
\text { of total }\end{array}$ & Average Price & Standard Deviation \\
\hline$>$ R200 & 256 & $3,11 \%$ & R 285,28 & R 101,59 \\
\hline R150 to R199,99 & 319 & $3,88 \%$ & $\mathrm{R} \quad 171,00$ & R 14,89 \\
\hline R100 to R149,99 & 410 & $4,98 \%$ & $\mathrm{R} \quad 115,05$ & $\mathrm{R} \quad 12,19$ \\
\hline $\mathrm{R} 50$ to $\mathrm{R} 99,99$ & 4781 & $58,13 \%$ & $\begin{array}{ll}\mathrm{R} & 71,91\end{array}$ & $\mathrm{R} \quad 14,05$ \\
\hline$>$ R50 & 2459 & $29,90 \%$ & R $\quad 37,14$ & $\begin{array}{ll}\mathrm{R} & 8,69 \\
\end{array}$ \\
\hline All wines & 8225 & $100,00 \%$ & R $\quad 76,17$ & R 52,95 \\
\hline
\end{tabular}

Table 7: The distribution of vintages across the 10 varietals $(n=8225)$

\begin{tabular}{|c|c|c|c|c|c|c|c|c|c|c|c|}
\hline 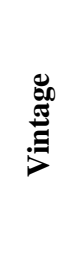 & 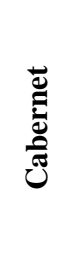 & $\frac{\overrightarrow{0}}{\grave{\Xi}}$ & 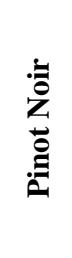 & 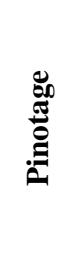 & 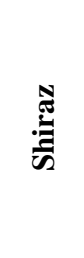 & 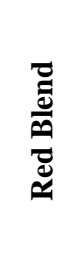 & 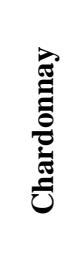 & 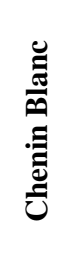 & 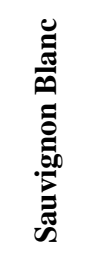 & 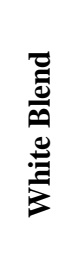 & 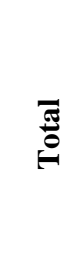 \\
\hline 1995 & 2 & 2 & 0 & 0 & 1 & 2 & 0 & 0 & 0 & 0 & 7 \\
\hline 1996 & 3 & 6 & 1 & 0 & 7 & 10 & 1 & 1 & 0 & 0 & 29 \\
\hline 1997 & 87 & 26 & 12 & 4 & 20 & 56 & 2 & 5 & 0 & 0 & 212 \\
\hline 1998 & 131 & 76 & 11 & 74 & 64 & 105 & 12 & 19 & 4 & 2 & 498 \\
\hline 1999 & 130 & 90 & 16 & 108 & 83 & 142 & 138 & 66 & 35 & 9 & 817 \\
\hline 2000 & 104 & 96 & 21 & 103 & 125 & 137 & 141 & 64 & 127 & 7 & 925 \\
\hline 2001 & 119 & 112 & 25 & 119 & 127 & 151 & 126 & 54 & 160 & 15 & 1008 \\
\hline 2002 & 120 & 89 & 18 & 105 & 177 & 212 & 136 & 42 & 140 & 9 & 1048 \\
\hline 2003 & 111 & 99 & 27 & 110 & 176 & 247 & 154 & 62 & 143 & 33 & 1162 \\
\hline 2004 & 97 & 98 & 23 & 110 & 199 & 222 & 135 & 60 & 157 & 52 & 1153 \\
\hline 2005 & 26 & 30 & 13 & 62 & 112 & 116 & 150 & 54 & 136 & 77 & 776 \\
\hline 2006 & 1 & 2 & 1 & 10 & 4 & 22 & 83 & 66 & 147 & 66 & 402 \\
\hline 2007 & 0 & 0 & 0 & 1 & 0 & 0 & 8 & 2 & 103 & 27 & 141 \\
\hline NV & 1 & 1 & 0 & 0 & 1 & 32 & 1 & 0 & 0 & 11 & 47 \\
\hline Total & 932 & 727 & 168 & 806 & 1096 & 1454 & 1087 & 495 & 1152 & 308 & 8225 \\
\hline
\end{tabular}

Table 8: A correlation matrix detailing the relationship between the variables across the entire dataset $(n=8225)$.

\begin{tabular}{|c|c|c|c|c|}
\hline & 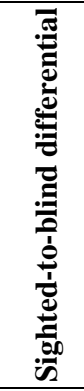 & D & 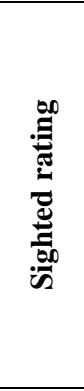 & : \\
\hline Sighted-to-blind differential & 1,00 & & & \\
\hline Blind rating & $-0,73$ & 1,00 & & \\
\hline Sighted rating & 0,34 & 0,39 & 1,00 & \\
\hline Price & 0,04 & 0,30 & 0,47 & 1,00 \\
\hline
\end{tabular}




\section{Results and discussion}

\section{Methodology and model construction}

On the basis of the descriptive statistics presented thus far, a series of varietal-specific stepwise regressions is developed to explain and contrast functional and symbolic branddriven explanations of intrinsic wine quality and the sightedto-blind differential, respectively. So doing, the crosssection of blind scores and sighted-minus-blind scores is modelled for the similar goods $\mathrm{i}=1 \ldots \mathrm{n}$ as a function of $\mathrm{K}$ "quality cue" $\left(\mathrm{QC}_{\mathrm{k}}\right.$ where $\left.\mathrm{k}=1, \ldots, \mathrm{K}\right)$ characteristics. As already discussed, the classification of the explanatory variables (QC) includes only those that are likely to influence hedonic quality: in the case of blind tastings the intrinsic influence of vintage and the functional quality of the wine-brand in question; and in the case of sighted tastings, the perceived effects of vintage, price and winebrand. The following equations are hence estimated using OLS:

Blind score $_{\mathrm{i}}=\alpha+\sum_{\mathrm{k}=1}^{\mathrm{K}} \mathrm{b}_{\mathrm{k}} \mathrm{QC}_{\mathrm{k}}+\varepsilon_{\mathrm{i}} \quad \cdots$

to identify functional brands, and

(Sighted minus Blind) score ${ }_{\mathrm{i}}=\alpha+\sum_{\mathrm{k}=1}^{\mathrm{K}} \mathrm{b}_{\mathrm{k}} \mathrm{QC}_{\mathrm{k}}+\varepsilon_{\mathrm{i}} \quad \cdots$

to identify symbolic brands,

where

$\alpha=$ the estimated intercept term

$\mathrm{b}=$ the estimated $\mathrm{K}$ slope coefficients

$\mathrm{QC}=$ the $\mathrm{K}$ 'quality cues': namely vintage, brand and in the sole instance of "sight minus blind" scores, price.

$\varepsilon \quad=$ a random residual error term following classic assumptions

As with Priilaid (2007), the vintage variable is coded ("dummified") on a year-by-year basis in order to control for and quantify seasonal fluctuations in wine quality. Price is specified as a ratio variable and also disaggregated into five categorical price-bands namely: "0-R49.99", "R50R99.99", "100-149.99", "150-199.99" and "Over R200". Candidate brands are also treated as categorical variables and dummified. Additionally, the respective categorical vintage, price and brand comparators - "2001", "0-R49.99", and the brand designated as "Not Applicable" - are introduced to avoid the dummy trap (see Malhotra, 2007). This final variable accounts for all wine labels failing to meet the varietal-specific "six-or-more" brand-candidate specification. All brand-defined coefficients produced in the models that follow should hence be considered relative to these base comparators which, in turn, are represented by the constant term derived in each model.

The general varietal-specific regression equations describing the blind score and placebo for each wine, $i$, are laid out below.

Blind score $_{\mathrm{i}}=\alpha+\mathrm{b}_{1}\left(\right.$ Vintage $_{\mathrm{i}}+\mathrm{b}_{2}(\text { Brand })_{\mathrm{i}}$ where, respectively, $b_{1}$ and $b_{2}$ explains the inherent marginal effects of vintage and functional brands on intrinsic quality (blind scores), and

(Sighted-Blind) score $_{i}=\alpha+b_{1}(\text { Vintage })_{i}+b_{2}(\text { Brand })_{i}+b_{3}(\text { Price })_{i}$

where,

respectively, $b_{1}, b_{2}$ and $b_{3}$ explains the perceived marginal effects of vintage, symbolic brands and price on sightedminus-blind scores.

By controlling for vintage, we can strip out inter-seasonal effects; thus where they occur in equations 1 and 2 these effects are removed from the final computation. With respect to equation 1 it should be noted that vintage serves here as a production-side variable which will inherently affect the quality of a wine from one season to the next. By contrast, as a consumer-facing construct, price has no determining influence on a wine's blind score and hence plays no part in equation 1 . Conversely, in equation 2, where identified, the price-effects for each wine (i) are computed since they remain constant across the sample ${ }^{2}$ irrespective of time. Where brands are identified as statistically significant, by controlling thus for vintage and price, equations 1 and 2 can be simplified so as to enable a computation for wineries that present with functional and symbolic brand effects:

From (1):

Blind score ${ }_{i}=\alpha+b_{2}(\text { Brand })_{i}$

here $b_{2}$ explains the functional brand effect of brand $i$.

And from (2):

(Sighted-Blind) score $_{\mathrm{i}}=\alpha+\mathrm{b}_{2}(\text { Brand })_{\mathrm{i}}+\mathrm{b}_{3}\left(\right.$ Price $_{\mathrm{i}}$

where

$b_{2}$ explains the symbolic brand effect of brand $i$. Where identified the effect of price controls can be noted through $b_{3}$.

In summary, "functional" brands are thus identified as those brands which present with statistically significant assessments of intrinsic quality as proxied here by the blind score computation in equation 3 , and imply an additional increment $\left(b_{2}\right)$ above or below the model constant / mean $(\alpha)$.

In contrast "symbolic" brands are denoted by a statistically significant difference between a wine's intrinsic and extrinsic merit, and as per equation 4, also imply an increment $\left(b_{2}\right)$ above or below the sample constant $(\alpha)$ though this time factoring in potential price controls as per $b_{3}$.

The results of the twenty regression models derived are depicted below in Tables 9 and 10 .

${ }^{1}$ This is not the case with vintage. 
With respect to the findings outlined in Tables 9 and 10, a number of observations are appropriate.

1. Symbolic (placebo) and functional (blind-based) brand effects are identified in all twenty models. Statistically significant vintage effects are identified in all but the cabernet blind model and both versions of the pinot noir model. As with Priilaid (2007), an analysis of the vintage coefficients demonstrates the extent to which seasonal variability can affect the quality of different cultivar wines in different ways (blind versus sighted- to-blind) from one year to the next (see Table 11 below). Ratio-styled pricing effects appear in the sighted-less-blind pinotage, red blend and chardonnay models. In the pinotage, red blend, sauvignon-blanc and white blend models, the categorical pricing variable "R50 to R99,99" is also significant. In unreported tests, potential collinearity between ratio prices and price bands was not found to influence results.

Table 9: Estimated red varietal regressions explaining blind and sighted minus blind wine assessments with controls for vintage and price. Where statistically significant at the 5\% level, model variables appear, with their respective coefficients and t-statistics in parenthesis, in the sequence: constant, vintage, price (for symbolic effects), and brand. Each variable is sorted by order of $t$-stat. (Note that with price effects an additional two pinotage and six red blend symbolic brands are identified.)

\begin{tabular}{|c|c|}
\hline $\begin{array}{c}\text { Cabernet } \\
\text { Blind: } \text { Adj } R^{2}: 14,14 \%, F: 7,13(p=0,0001), n=932 \\
\text { Statistically significant brands: } 25 / 49\end{array}$ & $\begin{array}{c}\text { Cabernet } \\
\text { Sighted - Blind: Adj } R^{2}: 4,06 \%, F: 6,63(p=0,0000), n=932 \\
\text { Statistically significant brands: } 5 / 49\end{array}$ \\
\hline Constant: $(2,54,83,62)$. & Constant: $(1,00,31,43)$. \\
\hline \multirow[b]{2}{*}{$\begin{array}{l}\text { Functional Brands: Thelema }(1,21,4,62) \text {; Neil Ellis Vineyard Selection }(1,32 \text {, } \\
4,22) \text {; Rustenberg }(1,25,3,99) \text {; Cederburg }(0,91,3,48) \text {; Boekenhoutskloof }(0,96 \text {, } \\
3,28) \text {; De Trafford }(0,78,3,12) \text {; Fleur du cap }(0,78,3,12) \text {; Jordan }(0,84,2,86) \text {; } \\
\text { L'Avenir }(0,77,2,64) \text {; Stony Brook }(0,77,2,64) ; \text { Le Riche }(0,63,2,62) ; \text { Morganhof } \\
(0,88,2,60) \text {; Waterford }(0,88,2,60) \text {; Flagstone }(0,71,2,43) \text {, Spier }(0,71,2,43) \text {; Bon } \\
\text { Courage }(0,80,2,35) \text {; Nederburg Private Bin }(0,80,2,35) \text {; Vergelegen }(0,80,2,35) \text {; } \\
\text { Boland }(0,65,2,22) \text {; Stark Conde }(0,65,2,22) \text {; Blue Creek }(0,68,2,16) ; \text { Eikendal } \\
(0,68,2,16) \text {; Longridge }(0,71,2,11) \text {; Nederburg straight cabs }(-0,87,-2,58) \text {; } \\
\text { Diemersdal }(-0,90,-2,86) \text {. }\end{array}$} & Vintage: Yr $2004(-0,28,-3,04)$; Yr $2003(-0,24,-2,82)$ \\
\hline & $\begin{array}{l}\text { Symbolic Brands: Diemersdal }(1,11,3,51) \text {; Hoopenburg }(0,71,2,07) \text {; } \\
\text { Nederburg all cabs }(0,50,2,06) \text {; Eikendal }(-0,64,-2,02) \text {; Nederburg } \\
\text { Private Bin }(-1,25,-2,98) .\end{array}$ \\
\hline $\begin{array}{c}\text { Merlot } \\
\text { Blind: } \text { Adj } R^{2}: 11,40 \%, F: 8,79(p=0,0000), n=727 \\
\text { Statistically significant brands: } 11 / 36\end{array}$ & $\begin{array}{c}\text { Merlot } \\
\text { Sighted - Blind: } \text { Adj } R^{2}: \text { 7,31\%, } F: 8,15(p=0,0010), n=727 \\
\text { Statistically significant brands: } 7 / 36\end{array}$ \\
\hline Constant: $(2,63,77,18)$ & Constant: $(0,81,23,57)$ \\
\hline Vintage: Yr $2004(-0,52,-5,97)$ & Vintage: Yr $2004(0,39,4,27)$. \\
\hline $\begin{array}{l}\text { Functional Brands: Thelema Reserve }(1,46,4,41) \text {; Morganhof }(0,75,2,61) \text {; Steen- } \\
\text { berg }(0,75,2,61) \text {; De Trafford }(0,65,2,41) \text {; Rust en Vrede }(0,63,2,18) \text {; Veen- } \\
\text { wouden }(0,71,2,13) \text {; Spier }(0,54,2,00) \text {; Thelema }(0,54,2,00) \text {; Bilton }(-0,71 \text {, } \\
-2,13) \text {; Kleine Zalze }(-0,71,-2,14) \text {; Landskroon }(-0,70,-2,26) \text {. }\end{array}$ & $\begin{array}{l}\text { Symbolic Brands: Bilton }(1,29,3,77) \text {; Cordoba }(1,05,3,29) \text {; Kanu } \\
(0,75,2,53) \text {; Overgaauw }(0,78,2,45) \text {; Eikendal }(0,79,2,31) \text {; Kleine } \\
\text { Zalze }(0,77,2,25) \text {; Meerlust }(0,69,2,17) \text {. }\end{array}$ \\
\hline $\begin{array}{c}\text { Pinotage } \\
\text { Blind: } \operatorname{Adj} R^{2}: 12,46 \%, F: 9,81(p=0,0000), n=806 \\
\text { Statistically significant Brands: } 11 / 43\end{array}$ & $\begin{array}{c}\text { Pinotage } \\
\text { Sighted - Blind: } \text { Adj } R^{2}: \text { 4,06\%, } F: 5,26(p=0,0000), n=806 \\
\text { Statistically significant Brands: } 5(+2) / 43\end{array}$ \\
\hline Constant: $(2,56,71,69)$ & Constant: $(0,71,8,41)$. \\
\hline Vintage: Yr $2004(-0,30,-3,43)$; Yr $2002(-0,18,-2,04)$. & Vintage: Yr $1999(-0,24,-2,54)$. \\
\hline \multirow{2}{*}{$\begin{array}{l}\text { Functional Brands: Kanonkop }(1,38,4,67) \text {; L'Avenir }(1,03,4,27) \text {; Moreson } \\
(1,00,3,40) \text {; Simonsig Red Hill }(0,94,3,38) \text {; De Waal }(0,91,2,86) \text {; Delheim }(0,80 \text {, } \\
2,53) \text {; Beyerskloof Reserve }(0,86,2,51) \text {; Spice Route }(0,62,2,35) \text {; Southern Right } \\
(0,73,2,30) \text {; Kleine Zalze }(-0,98,-2,87) \text {; Porterville }(-1,31,-3,85) \text {. }\end{array}$} & Price: R50 to R99,99 $(0,16,2,41)$; Ratio $(0,0019,2,11)$. \\
\hline & $\begin{array}{l}\text { Symbolic Brands: Porterville }(1,11,2,97) \text {; Beyerskloof standard }(0,80 \text {, } \\
2,43) \text {; Kaapzicht }(0,54,1,90) \text {; Delheim }(-0,73,-2,10) \text {; Moreson }(-0,89 \text {, } \\
-2,74) \text {. }\end{array}$ \\
\hline $\begin{array}{c}\text { Pinot Noir } \\
\text { Blind: } \text { Adj } R^{2}: 14,83 \%, F: 10,69(p=0,0000), n=168 \\
\text { Statistically significant brands: } 3 / 10\end{array}$ & $\begin{array}{c}\text { Pinot Noir } \\
\text { Sighted - Blind: Adj } R^{2}: 9,15 \%, F: 17,83(p=0,0000), n=168 \\
\text { Statistically significant brands: } 1 / 10\end{array}$ \\
\hline Constant: $(2,48,34,41)$. & Constant: $(0,98,14,52)$. \\
\hline $\begin{array}{l}\text { Functional Brands: Hamilton Russell }(1,07,3,66) \text {; Bouchard Finlayson }(0,67 \text {, } \\
2,71) \text {; Cabrière }(-1,15,-3,23) \text {. }\end{array}$ & Symbolic Brands: Cabrière $(1,52,4,22)$. \\
\hline $\begin{array}{c}\text { Shiraz } \\
\text { Blind: } \text { Adj } R^{2}: 9,66 \%, F: 6,86(p=0,0000), n=1096 \\
\text { Statistically significant brands: } 19 / 60\end{array}$ & $\begin{array}{c}\text { Shiraz } \\
\text { Sighted - Blind: } \text { Adj } R^{2}: \text { 1,56\%, } F: 5,33(p=0,0003), n=1096 \\
\text { Statistically significant brands: } 3 / 60\end{array}$ \\
\hline Constant: $(2,70,85,60)$ & Constant: $(0,93,30,28)$ \\
\hline Vintage: Yr $2004(-0,28,-4,06)$ & Vintage: Yr $2004(0,18,2,50)$ \\
\hline $\begin{array}{l}\text { Functional Brands: Stellenzicht }(0,09,3,54) \text {; Boekenhoutskloof }(1,12,3,37) \text {; The } \\
\text { Sadie Family }(1,02,3,06) \text {; Graham Beck }(0,83,2,95) \text {; Saxenburg Private Collec- } \\
\text { tion }(1,01,2,81) \text {; Spice Route flagship syrah }(0,91,2,72) \text {; Waterford }(0,96,2,67) ; \\
\text { Simonsig Merindol }(0,83,2,67) \text {; De Trafford }(0,61,2,57) \text {; Hartenberg }(0,75,2,54) \text {; } \\
\text { Diemesfontein }(0,70,2,52) \text {; Avondale }(0,80,2,39) \text {; Glen Carlou }(0,84,2,34) \text {; The- } \\
\text { lema }(0,73,2,20) \text {; Fairview premium shirazes }(0,50,2,19) \text {; Boschendal }(0,58 \text {, } \\
\text { 2,16); Neil Ellis Vineyard Selection }(0,71,1,98) \text {; Blaauwklippen }(-0,74,-2,05) \text {; } \\
\text { Boplaas }(-0,87,-2,41) \text {. }\end{array}$ & $\begin{array}{l}\text { Symbolic Brands: Kloovenburg }(0,76,2,22) \text {; Stellenzicht }(-0,57 \text {, } \\
-2,15) \text {; Diemesfontein }(-0,66,-2,30) \text {. }\end{array}$ \\
\hline
\end{tabular}




\begin{tabular}{|c|c|}
\hline $\begin{array}{c}\text { Red Blends } \\
\text { Blind: } \text { Adj } R^{2}: 10,74 \%, F: 9,74(p=0,0000), n=1454 \\
\text { Statistically significant brands: } 19 / 79\end{array}$ & $\begin{array}{c}\text { Red Blends } \\
\text { Sighted - Blind: } \text { Adj } R^{2}: 7,36 \%, F: 6,49(p=0,0000), n=1454 \\
\text { Statistically significant brands: } 16(+6) / 79\end{array}$ \\
\hline Constant: $(2,59,108,49)$. & Constant: $(0,79,16,26)$. \\
\hline Vintage: Yr $1998(0,25,2,98)$. & $\begin{array}{l}\text { Vintage: Yr } 1997(-0,25,-2,16) \text {; Yr } 1998(-0,23,-2,67) \text {; Yr } 2005(-0,23 \text {, } \\
-2,77) \text {. }\end{array}$ \\
\hline \multirow[b]{2}{*}{$\begin{array}{l}\text { Functional Brands: Ernie Els Wines }(1,35,4,59) \text {; Vergelegen }(1,01,4,22) \text {; De } \\
\text { Toren Fusion V }(1,27,4,04) \text {; Jordan Cobbler's Hill }(1,60,3,85) \text {; Glen Carlou } \\
(0,86,3,85) \text {; Kanonkop Paul Sauer }(1,16,3,70) \text {; Rust en Vrede }(1,16,3,70) \text {; } \\
\text { Rustenberg }(1,16,3,70) \text {; Morganhof }(1,02,3,24) \text {; Simonsig }(0,59,2,90) \text {; Rupert } \\
\text { and Roths-child }(0,69,2,48) \text {; Yonder Hill Winery }(0,78,2,32) \text {; Grangehurst }(0,61 \text {, } \\
\text { 2,32); Raka }(0,63,2,28) \text {; Flagstone }(0,44,2,17) \text {; Beyerskloof }(0,51,2,14) \text {; Rem- } \\
\text { hoogte }(0,60,2,04) \text {, Welgemeend }(-0,74,-2,80) \text {; Nederburg }(-0,77,-3,08) \text {. }\end{array}$} & Price: Ratio $(0.0013,3.70), \mathrm{R} 50$ to R99.99 $(0.17,3.51)$. \\
\hline & $\begin{array}{l}\text { Symbolic Brands: Welgemeend }(0,95,3,50) \text {; Nederburg Edelrood } \\
(1,11,2,94) \text {; Asara }(0,86,2,50) \text {; Alto Rouge }(0,72,2,26) \text {; Veenwouden } \\
\text { Classic }(0,78,2,25) \text {; Morganhof }(-0,63,-1,98) \text {, Kanu }(-0,52,-2,06) \text {; Ver- } \\
\text { gelegen }(-0,52,-2,08) \text {; Groot Constantia }(-0,56,-2,22) \text {; Raka }(-0,62,- \\
\text { 2,23); Rust en Vrede }(-0,73,-2,25) \text {; Fairview }(-0,60,-2,34) \text {; Ernie Els } \\
\text { Wines }(-0,87,-2,67) \text {; Jordan }(-0,73,-2,75) \text {; Cederburg }(-0,91,-3,41) \text {; } \\
\text { Glen Carlou }(-0,90,-4,00) \text {. }\end{array}$ \\
\hline
\end{tabular}

Table 10: Estimated white varietal regressions explaining blind and sighted minus blind wine assessments with controls for vintage and price. Where statistically significant at the 5\% level, model variables appear, with their respective coefficients and t-statistics in parenthesis in the sequence: constant, vintage, price (for symbolic effects), and brand. Each variable is sorted by order of $t$-stat. (Note that with price effects an additional chardonnay symbolic brand is identified.)

\begin{tabular}{|c|c|}
\hline $\begin{array}{c}\text { Chardonnay } \\
\text { Blind: Adj } R^{2}: 18,35 \%, F: 9,71(p=0,0000), n=1087 \\
\text { Statistically significant brands: } 26 / 66\end{array}$ & $\begin{array}{c}\text { Chardonnay } \\
\text { Sighted - Blind: } \text { Adj } R^{2}: 7,78 \%, F: 10,16(p=0,0000), n=1087 \\
\text { Statistically significant brands: } 7(+1) / 66\end{array}$ \\
\hline Constant: $(2,28,69,65)$ & Constant: $(0,86,14,72)$. \\
\hline Vintage: Yr $2005(0,22 ; 2,90)$, Yr $2000(-0,20,-2,66)$ & Vintage: Yr $2000(0,24,3,12)$; Yr $2003(0,19,2,57)$. \\
\hline \multirow[b]{2}{*}{$\begin{array}{l}\text { Functional Brands: Jordan }(1,20,5,15) \text {; Mulderbosch Barrel Fermented }(1,55 \text {, } \\
\text { 4,88); Cape Chamonix }(1,14,4,48) \text {; Vergelegen }(0,95,4,38) \text {; Fleur du Cap } \\
\text { Unfiltered }(1,36,4,30) \text {; Fairview }(1,21,4,07) \text {; Rustenberg }(0,95,3,92) \text {; Avontuur } \\
(1,04,3,73) \text {; Hamilton Russell }(1,09,3,69) \text {; Amani }(1,08,3,65) \text {; Eikendal }(0,86 \text {, } \\
\text { 3,55); Thelema (not Ed's) }(1,03,3,48) \text {; Rupert and Roths-child }(1,18,3,46) ; \\
\text { Boschendal }(0,72,3,08) \text {; Newton Johnson }(0,89,2,81) \text {; Buitenverwachting }(0,75 \text {, } \\
\text { 2,81); Glen Carlou }(0,61,2,61) \text {; Longridge }(0,88,2,59) \text {; Groot Constantia }(0,82 \text {, } \\
\text { 2,59); Groote Post Wooded }(0,67,2,52) \text {; Warwick Estate }(0,79,2,49) \text {; Plasir de } \\
\text { Merle (0,80, 2,34); Diemersdal }(0,69,2,17) \text {; Neil Ellis }(0,44,2,01) \text {; Bouchard } \\
\text { Finlayson Sans Barrique }(-0,82,-2,39) \text {; Dieu Donné }(-0,90,-2,63) \text {. }\end{array}$} & Price: Ratio $(0.0016,2.30)$ \\
\hline & $\begin{array}{l}\text { Symbolic Brands: Bouchard Finlayson all chardonnay }(1,33,5,66) \text {; } \\
\text { Rhebokskloof Grand Reserve }(0,94,2,76) \text {; Amani }(-0,60,-2,04) ; \\
\text { Avontuur }(-0,80,-2,85) \text {; Bouchard Finlayson Kaaimansgat }(-1,20,- \\
3,06) \text {; Mulderbosch Barrel Fermented }(-1,14,-3,54) \text {; } \\
\text { Boland }(-1,34,-3,91) \text {. }\end{array}$ \\
\hline $\begin{array}{c}\text { Chenin Blanc } \\
\text { Blind: } \text { Adj } R^{2}: 21,48 \%, F: 10,01(p=0,0008), n=495 \\
\text { Statistically significant brands: } 10 / 23\end{array}$ & $\begin{array}{c}\text { Chenin Blanc } \\
\text { Sighted - Blind: } \text { Adj } R^{2}: 11,51 \%, F: 9,03(p=0,0000), n=495 \\
\text { Statistically significant brands: } 5 / 23\end{array}$ \\
\hline Constant: $(2,67,44,87)$. & Constant: $(0,67,13,97)$ \\
\hline $\begin{array}{l}\text { Vintage: Yr } 2002(-0,39,-2,64), \text { Yr } 1998(-0,77,-3,69) \text {; Yr } 2006 \\
(-0,41,-3,34) \text {; Yr } 2000(-0,61,-4,97) \text {; Yr } 1999(-0,84,-6,97) .\end{array}$ & $\begin{array}{l}\text { Vintage: Yr } 1998(0,72,3,48) \text {; Yr } 1999(0,40,3,44) \\
\text { Yr } 2005(-0,28,-2,16)\end{array}$ \\
\hline $\begin{array}{l}\text { Functional Brands: Kanu Wooded }(1,72,4,83) \text {; Rijks }(1,08,3,03) \text {; Rudera }(0,82, \\
2,95) \text {; Spice Route }(0,95,2,85) \text {; Ken Forrester }(0,55,2,69) \text {; De Trafford }(0,59, \\
2,22) \text {; Hazendal }(0,79,2,20) \text {; Mulderbosch Steen op Hout }(0,69,2,09) \text {; Spier } \\
(0,74,2,08) \text {; Landskroon }(-0,90,-2,89) \text {. }\end{array}$ & $\begin{array}{l}\text { Symbolic Brands: Beaumont }(0,73,3,05) \text {; Raats }(1,02,3,04) \text {; Hazendal } \\
(-0,84,-2,33) \text {, Simonsig }(-0,76,-2,58) \text {; Kanu Wooded }(-1,02,-2,84) .\end{array}$ \\
\hline $\begin{array}{c}\text { Sauvignon Blanc } \\
\text { Blind: } \text { Adj } R^{2}: 17,68 \%, F: 10,51, n=1152 \\
\text { Statistically significant brands: } 22 / 75\end{array}$ & $\begin{array}{c}\text { Sauvignon Blanc } \\
\text { Sighted - Blind: Adj } R^{2}: 7,61 \%, F: 6,58(p=0,0000), n=1152 \\
\text { Statistically significant brands: } 13 / 75\end{array}$ \\
\hline Constant: $(2,10,57,74)$. & Constant: $(1,05,24,43)$. \\
\hline $\begin{array}{l}\text { Vintage: Yr } 2006(0,57,7,26) \text {; Yr } 2005(0,46,5,67), \text { Yr } 2007(0,28 ; 3,06) ; \text { Yr } \\
2004(0,24,3,08) .\end{array}$ & $\begin{array}{l}\text { Vintage: Yr } 2005(-0,18,-2,17) ; \text { Yr } 2006(-0,22,-2,76) ; \text { Yr } 1999 \\
(-0,46,-2,97) \text {. }\end{array}$ \\
\hline \multirow[b]{2}{*}{$\begin{array}{l}\text { Functional Brands: Cape Point Vineyards }(1,38,5,76) \text {; Springfield }(1,24,5,74) \text {; } \\
\text { Steenberg Reserve }(1,39,4,59) \text {; Vergelegen }(0,92,3,99) \text {; Fleur du Cap Unfiltered } \\
(1,00,3,48) \text {; Kumkani }(0,78,2,99) \text {; Neil Ellis }(0,89,2,94) \text {; Tokara }(0,75,2,89) ; \\
\text { Jordan }(0,65,2,83) \text {; Spier Private Collection }(0,89,2,54) \text {; Mooi-plaas }(0,87,2,47) \text {; } \\
\text { Cederburg }(0,71,2,32) \text {; Groote Post }(0,71,2,32) \text {; Graham Beck }(0,66,2,32) \text {; Bon } \\
\text { Courage }(0,75,2,31) \text {; Mulderbosch }(0,58,2,22) \text {; Iona }(0,77,2,20) \text {; Bloemendal } \\
(0,62,2,03) \text {; Nitida }(0,52,2,02) \text {; Thelema }(0,49,1,99) \text {; Steenberg standard }(0,54 \text {, } \\
1,98) \text {; Swartland }(-0,74,-2,28) \text {. }\end{array}$} & Price: R50 to R99,99 $(0,11,2,02)$. \\
\hline & $\begin{array}{l}\text { Symbolic Brands: Villiera Traditional Bush Vine }(0,85,2,46) \text {; Southern } \\
\text { Right }(0,71,2,20) \text {; Lushof }(0,73,2,11) \text {; Backsberg }(-0,68,-1,98) ; \\
\text { Landskroon }(-0,76,-2,06) \text {; Kanu }(-0,61,-2,13) \text {; Graham Beck }(-0,66 \text {, } \\
-2,18) \text {; Mooiplaas }(-0,89,-2,39) \text {; Kleine Zalze }(-0,82,-2,56) \text {; Du } \\
\text { Toitskloof }(-0,98,-2,63) \text {; Cape Point Vineyards }(-0,73,-2,89) \text {; Spring- } \\
\text { field }(-0,89,-3,88) \text {; Bon Courage }(-1,34,-3,91) \text {. }\end{array}$ \\
\hline $\begin{array}{c}\text { White Blends } \\
\text { Blind: Adj } R^{2}: 11,01 \%, F: 10,49(p=0,0000), n=308 \\
\text { Statistically significant brands: } 2 / 8\end{array}$ & $\begin{array}{c}\text { White Blends } \\
\text { Sighted - Blind: } \text { Adj } R^{2}: 10,74 \%, F: 8,39(p=0,0000), n=308 \\
\text { Statistically significant brands: } 1 / 8\end{array}$ \\
\hline Constant: $(2,41,41,55)$. & Constant: $(0,62,9,87)$. \\
\hline Vintage: Yr $2006(0,44,3,60)$; Yr $2000(-1,00,-2,97)$. & $\begin{array}{l}\text { Vintage: Yr } 2000(1,26,3,93) \text {; Yr } 2006(-0,25,-2,13) \text {; Yr } 2007 \\
(-0,41 ;-2,45)\end{array}$ \\
\hline \multirow[t]{2}{*}{ Functional Brands: Vergelegen $(1,10,3,06)$; Rhebokskloof $(-0,83,-2,46)$. } & Price: R50 to R99,99 $(0,39,3,30)$ \\
\hline & Symbolic Brands: Woolworths $(-0,64,-2,61)$. \\
\hline
\end{tabular}


2. Across all 20 models the average $p$ value derived from the relevant $\mathrm{F}$ statistic is less than 0,0000 . However, the F statistics derived from the blind-based models are marginally greater than those from the sighted-lessblind. Across the ten cultivars, the mean blind and sighted-to-blind F statistics are 9,37 and 8,39, respectively. In all instances, the blind-based-models identify more brand effects than do the sighted-to-blind models. This aligns with market realities. By far the majority of the 448 candidate brands (276 red, 172 white) are small and medium-sized (SME) wineries which focus more on product-driven as opposed to market-driven branding. In line with the disproportionate number of SME wineries, the consequent emergence of a rich suite of functional production-driven brands (148 in all) and a far smaller set of symbolic "placebo"-type brands (72 after price effects) is therefore not surprising, and confirms the work of Lockshin et al., (2000), Kivetz and Simonson, (2002b), and Mowle and Merrilees (2005), inter-alia. More so, evolutionary psychology reminds us that neurological cues such as brands are functional first and then, only later, and on the basis of their demonstrable functionality, symbolic. This functional-to-symbolic migration is the genesis of all placebo effects (Montague, 2006), and adds further explanation to the disproportionate ratio outlined above.

Table 11: Vintage effects as per the twenty models developed. Note 2001 is the control year.

\begin{tabular}{|c|c|c|}
\hline Blind Vintage Effects & Vintage & Sighted-to-Blind Vintage Effects \\
\hline Nil. & 1997 & $(-0,25)$ red blend \\
\hline $\begin{array}{c}(0,25) \text { red blend } \\
(-0,77) \text { chenin blanc }\end{array}$ & 1998 & $\begin{array}{l}(-0,23) \text { red blend } \\
(0,72) \text { chenin blanc }\end{array}$ \\
\hline$(-0,84)$ chenin blanc & 1999 & $\begin{array}{c}(-0,24) \text { pinotage } \\
(0,40) \text { chenin blanc } \\
(-0,46) \text { sauvignon blanc }\end{array}$ \\
\hline $\begin{array}{l}(-0,20) \text { chardonnay } \\
(-0,61) \text { chenin blanc } \\
(-1,00) \text { white blends }\end{array}$ & 2000 & $\begin{array}{l}(0,24) \text { chardonnay } \\
(1,26) \text { white blends }\end{array}$ \\
\hline Control & 2001 & Control \\
\hline $\begin{array}{c}(-0,18) \text { pinotage } \\
(-0,39) \text { chenin blanc }\end{array}$ & 2002 & Nil. \\
\hline Nil. & 2003 & $\begin{array}{c}(-0,24) \text { cabernet } \\
(0,19) \text { chardonnay }\end{array}$ \\
\hline $\begin{array}{c}(-0,30) \text { pinotage } \\
(-0,52) \text { merlot } \\
(-0,28) \text { shiraz } \\
(0,24) \text { sauvignon blanc }\end{array}$ & 2004 & $\begin{array}{c}(-0,28) \text { cabernet } \\
(0,39) \text { merlot } \\
(0,18) \text { shiraz }\end{array}$ \\
\hline $\begin{array}{c}(0,22) \text { chardonnay } \\
(0,46) \text { sauvignon blanc }\end{array}$ & 2005 & $\begin{array}{c}(-0,23) \text { red blend } \\
(-0,28) \text { chenin blanc } \\
(-0,18) \text { sauvignon blanc }\end{array}$ \\
\hline $\begin{array}{c}(-0,41) \text { chenin blanc } \\
(0,57) \text { sauvignon blanc } \\
(0,44) \text { white blends }\end{array}$ & 2006 & $\begin{array}{l}(-0,22) \text { sauvignon blanc } \\
(-0,25) \text { white blends }\end{array}$ \\
\hline$(0,28)$ sauvignon blanc & 2007 & $(-0,41)$ white blends \\
\hline
\end{tabular}

3. The 30 strongest blind-based and sighted-to-blind brand effects developed in this study are depicted in Table 12 below. Top blind-functional brands are dominated by shiraz (9/30) and red blends (8/30). This list showcases remarkable levels of competence with these two styles of wine-making, and as a composite of all cultivars vindicates the popular views of wine-making excellence as per the top-winery-list voted by WINE magazine readers featured in Table 1. Worth noting are the Fleur $d u$ Cap Unfiltered chardonnay and the shiraz from Stellenzicht (3,64 and 3,61 (blind) stars respectively). Both brands fit within the Distell stable - and consequently carry with them the connotation of being treated as part of a stable of commodity-type wine brands. This notwithstanding, their record of intrinsic merit suggests that these are indeed high-quality production-driven brands.

While more shall be said of those wines that conform to both types of branding effect, it is worth considering, for a moment, those top intrinsic-quality wines that do not. Why do wines like the Neil Ellis cabernet and the De Toren Fusion $V$ not present as placebo effects? This result would accord with the work of product-benefit researchers like Kivetz and Simonson (2002b) and Chitturi, Raghunathan and Mahajan (2008) (inter-alia), who report that functional "need" related benefits normatively accrue first in the mind of the consumer before symbolic "want" benefits can be considered.

Turning to the matter of how this process unfolds over time, we posit that if brands really are evolutionary phenomena then, in time, given a consistent level of intrinsic quality, functional brand effects should ultimately convert into symbolic placebo-effects. Montague (2006) develops this line of thought, using a set of theories related to computational neuroscience known as the temporal-difference reinforcement learning (TDRL) models (see also Montague et al., 2004). 
"The progression of learning in TDRL goes as follows. A stimulus that delivers reward, such as a juice squirt in the mouth, causes a transient burst of dopamine neurons signalling (to) the rest of the brain, "That was better than expected." Now suppose that a light consistently precedes this squirt of juice. Through multiple rounds of the experience - "light predicts juice about six seconds later," and so on - a TDRL system transfers the value associated with the receipt of juice to the earliest stimulus that predicts it - here the light. The light now has a value, or more precisely it's a proxy for something of value that will arrive six seconds into the future. At this point, an unanticipated onset of the light will cause a dopamine burst that means "better than expected," but only because it has consistently predicted a future event of real value (juice squirt). This value-passing scheme is powerful and allows values from all kinds of complex interactions to transfer back in time to stimuli in the world that predict them. The trick is that once these values correctly anticipate future reward, the system stops learning - the values match reality and so they do not need modifying" (Montague, 2006: 147-148).

To conclude this argument within the context of this study, once these values hold steady over time they become reputational proxies of hedonic quality, and this, we suggest, is precisely what all brands do.

4. Merlot wineries dominate the top 30 symbolic-placebo brands (7/30) featured in the right-hand column of Table 12. The balance is distributed (relatively) evenly amongst the remaining varietals, white blends excluded. These 30 brand effects, it should be noted, dramatise those wineries with the widest sight-to-blind differentials. With relatively low levels of intrinsic merit, the brand-equity differential is explained by a high degree of "experiential", non-substantial marketdriven values, and, conversely, a lower proportion of production values. Within this grouping, three potential sub-types emerge: (1) high-volume brands driven by substantial marketing budgets like Distell's Nederburg Edelrood (red-blend), Nederburg's standard cabernetsauvignon, and Alto as well as Du Toit's Kloof sauvignon blanc; (2) second-tier (also) high-volume wines that trade, by association, on the quality of their top-rated elders (for example, the standard Beyerskloof pinotage, and the Missionvale and Sans Barrique chardonnays from Bouchard Finlayson), and (3) certain brands that might once have delivered intrinsic merit, but no longer do - although they still register, extrinsically, as high quality brands. Here apt examples include the Welgemeend red blend (South Africa's first Bordeaux blend), the Cabrière pinot noir, and the merlots from Cordoba, Eikendal and Overgaauw. The preponderance of merlots within this list suggests also that this third mechanism might apply too to certain cultivars (like merlot) which, while still held in high esteem, no longer produce the consistent intrinsic quality wines they were once remembered for.

5. A further two symbolic brands are worth noting: the Cape Point Vineyards sauvignon-blanc and the Raka red blend. Both feature on the list of top emerging wineries featured in Table 1, and are listed too as functional brands though not in the top 30 (predicted blind scores of 3,48 and 3,22 respectively). Their identical sighted-to-blind differential $(0,43)$ is small, and consequently neither appears in Table 12.

6. To restate: notionally, we can imagine brands that present as placebo effects. These are symbolic brands that is to say, brands with statistically predictable sighted-to-blind differentials. Similarly, brands can also present as functional brands: that is to say, brands with a predictable intrinsic merit. In certain cases these two brand classes can overlap, enabling a brand to be simultaneously both functional and symbolic. This study identifies 35 such brands (see Table 13). Analysis suggests that these 35 decompose into two sub-clusters.

As depicted in Figure 2, the smaller cluster $(\mathrm{n}=9)$ presents with negative functionality $(\mathrm{M}=1,69, \quad \mathrm{t}=$ $14,72)$ and large placebos $(M=2,02, t=16,45)$. In contrast to their more expensive cousins, these placebos are underpinned by lower levels of intrinsic quality and a far greater media spend. This form of branding is marketing-driven, not production-driven. The onemillion-plus cases per annum Nederburg brand is case in point. In the red-blend stable, its Edelrood sub-brand consistently delivers an unremarkable 1,82 stars when tasted blind, but 4 stars when tasted sighted. As per the functional and symbolic pinot-noir models, the Cabrière brand does roughly the same: 1,33 stars blind, and 3,83 sighted. Noting the 3,51 mean average of all sighted assessments, sighted inspection suggests the Edelrood and Cabrière pinot appear as better-thanaverage wines (4 and 3,83 sighted stars respectively). Clearly, cues other than intrinsic merit are elevating the sighted pleasantness of these two wines.

Employing terminology from Bhat and Reddy (1998) and Mowle and Merrilees (2005), we can ascribe to this cluster low functional values (with all functional brand effect $\left(b_{2}\right)$ signs negative) and large symbolic values (with all symbolic brand effect $\left(b_{2}\right)$ signs positive). Explicitly this study therefore describes this first cluster as the Zone of Symbolic Values. One might loosely describe this as "the symbolic brands cluster", although strictly speaking this is not accurate. As per the specification of this paper, all placebos great and small are symbolic brands. Therefore, as per the model presented in Figure 1, more correctly we should call brands in this zone the symbolic and functional brands with high symbolic values where all symbolic brand effects $\left(b_{2}\right)$ are positive.

By comparison, the larger cluster in Figure $2(n=26)$ presents with small placebos $(\mathrm{M}=0,25, \quad \mathrm{t}=4,56$, $\mathrm{F}(1,33)=198,88, \mathrm{p}<0,0001)$ and high functionality $(\mathrm{M}=3,49, \mathrm{t}=14,10, \mathrm{~F}(1,33)=198,88, \mathrm{p}<0,0001)$. To this cluster one ascribes high functional values (with all functional brand effect $\left(b_{2}\right)$ signs positive) and low symbolic values (with all symbolic brand effect $\left(b_{2}\right)$ signs negative). Explicitly one may therefore describe this second cluster as the Zone of Functional Values, 
which in this instance may be more fully described as those symbolic and functional brands with high functional values where all functional brand effects $\left(b_{2}\right)$ are positive. Top-end red blends are a case in point and the preponderance of symbolic brand effects within this category (16 initial effects, although another 6 emerge through price controls) can be explained by the fact that most of these are top-quality flagship estate wines trading in the uppermost R200-plus price category.

Table 12: The top 30 brand effects identified for blind and sighted-to-blind assessments. Ratings for the blind and sighted-toblind models are fitted values and are derived from text-cited equations 3 and 4, respectively. They should be noted in relation to the blind and sighted-to-blind score averages of 2,59 and 0,92. Note: a single and double asterisk denotes a winery featured either as one South Africa's top rated wineries (*) or as one of the brands in the Distell stable (**) as per Table 1.

\begin{tabular}{|c|c|c|c|c|}
\hline \multicolumn{3}{|c|}{ BLIND MODEL } & \multicolumn{2}{|c|}{ SIGHTED MINUS BLIND MODEL } \\
\hline & Brand and rating & Cultivar & Brand and differential & Cultivar \\
\hline 1 & Kanu Limited Release Wooded* $(4,39)$ & chenin blanc & Cabrière $(2,50)$ & pinot noir \\
\hline 2 & Jordan Cobblers Hill * $(4,19)$ & red blends & Bouchard Finlayson Missionvale $(2,40)$ & chardonnay \\
\hline 3 & Thelema Reserve* $(4,09)$ & merlot & Bouchard Finlayson Sans Barrique $(2,34)$ & chardonnay \\
\hline 4 & Ernie Els Wines* $(3,94)$ & red blends & Nederburg Edelrood $* *(2,15)$ & red blends \\
\hline 5 & Kanonkop* $(3,93)$ & pinotage & Diemersdal $(2,11)$ & cabernet \\
\hline 6 & Neil Ellis $(3,86)$ & cabernet & Bilton $(2,10)$ & merlot \\
\hline 7 & De Toren Fusion $V^{*}(3,86)$ & red blends & Villiera Traditional Bush Vine $(2,00)$ & sauv-blanc \\
\hline 8 & Mulderbosch Barrel Fermented $(3,83)$ & chardonnay & Welgemeend $(2,00)$ & red blends \\
\hline 9 & Boekenhoutskloof* $(3,83)$ & shiraz & Asara $(1,97)$ & red blends \\
\hline 10 & Rustenberg* $(3,79)$ & cabernet & Rhebokskloof Grand Reserve $(1,96)$ & chardonnay \\
\hline 11 & Thelema* $(3,75)$ & cabernet & Porterville $(1,91)$ & pinotage \\
\hline 12 & Rustenberg $(3,75)$ & red blends & Lushof $(1,88)$ & sauv- blanc \\
\hline 13 & Rust en Vrede $(3,75)$ & red blends & Veenwouden Classic $(1,87)$ & red blends \\
\hline 14 & Kanonkop Paul Sauer* $(3,75)$ & red blends & Southern Right $(1,86)$ & sauv-blanc \\
\hline 15 & Rijks $(3,75)$ & chenin blanc & Cordoba $(1,86)$ & merlot \\
\hline 16 & The Sadie Family* $(3,72)$ & shiraz & Alto** $(1,77)$ & red blends \\
\hline 17 & Saxenburg Private Collection $(3,71)$ & shiraz & Beyerskloof (standard) $(1,76)$ & pinotage \\
\hline 18 & Waterford $(3,67)$ & shiraz & Hoopenburg $(1,71)$ & cabernet \\
\hline 19 & Fleur du Cap Unfiltered $* *(3,64)$ & chardonnay & Kloovenburg $(1,69)$ & shiraz \\
\hline 20 & Spice Route $(3,61)$ & chenin blanc & Raats $(1,68)$ & chenin blanc \\
\hline 21 & Spice Route flagship wines $(3,61)$ & shiraz & Eikendal $(1,60)$ & merlot \\
\hline 22 & Stellenzicht** $(3,61)$ & shiraz & Overgaauw $(1,59)$ & merlot \\
\hline 23 & Morganhof $(3,61)$ & red blends & Kleine Zalze $(1,58)$ & merlot \\
\hline 24 & Vergelegen* $(3,60)$ & red blends & Kaapzicht (standard) $(1,58)$ & pinotage \\
\hline 25 & L'Avenir $(3,59)$ & pinotage & Kanu* $(1,56)$ & merlot \\
\hline 26 & Moreson $(3,56)$ & pinotage & Meerlust $(1,50)$ & merlot \\
\hline 27 & Hamilton Russell* $(3,56)$ & pinot noir & Nederburg** $(1,50)$ & cabernet \\
\hline 28 & Glen Carlou $(3,55)$ & shiraz & Kaapzicht Stytler $(1,45)$ & pinotage \\
\hline 29 & Simonsig Merindol $(3,54)$ & shiraz & Beaumont $(1,39)$ & chenin blanc \\
\hline 30 & Graham Beck $(3,53)$ & shiraz & Bouchard Finlayson Kaaimansgat $(1,12)$ & chardonnay \\
\hline
\end{tabular}


Table 13: The 35 brands that qualify simultaneously with functional and symbolic/placebo effects. These brands are ranked by (reverse) order of the $b_{2}$ functional brand effect (column 3) used to derive the predicted blind score in column 4 . The figure in column four is added to the predicted placebo (sighted minus blind score) in column 6 to impute the sighted score in column 7. (All figures featured are derived from the models featured in Tables 9 and 10) This set of brands decomposes into the zones of Symbolic Value $(\mathrm{n}=9)$ and Functional Value $(\mathrm{n}=26)$ as illustrated in Figure 2 . Positive $b_{2}$ effects are shaded in light grey, negative effects in dark.

\begin{tabular}{c|c|c|c|c|c|c}
\hline 1 & 2 & 3 & 4 & 5 & 6 & 7 \\
\hline BRANDS & Varietal & $\begin{array}{c}\text { Functional } \\
\text { Brand } \\
\text { Effect } \\
\left(b_{2}\right)\end{array}$ & $\begin{array}{c}\text { Predicted } \\
\text { Blind } \\
\text { Score }\end{array}$ & $\begin{array}{c}\text { Symbolic } \\
\text { Brand } \\
\text { Effect } \\
\left(b_{2}\right)\end{array}$ & $\begin{array}{c}\text { Predicted } \\
\text { Placebo } \\
\text { (Sighted - } \\
\text { Blind Score) }\end{array}$ & $\begin{array}{c}\text { Imputed } \\
\text { Sighted } \\
\text { Score }\end{array}$ \\
\hline
\end{tabular}

BRANDS WITH HIGH SYMBOLIC VALUES

All symbolic brand effects are positive - all functional brand effects are negative.

\begin{tabular}{l|l|c|c|c|c|c|c}
\hline 1 & Porterville & pinotage & $-1,31$ & 1,25 & 1,11 & 1,91 & 3,16 \\
\hline 2 & Cabrière & pinot noir & $-1,15$ & 1,33 & 1,52 & 2,50 & 3,83 \\
\hline 3 & Bouchard Finlayson Sans-Barrique & chardonnay & $-0,82$ & 1,46 & 1,11 & 2,34 & 3,80 \\
\hline 4 & Diemersdal & cabernet & $-0,90$ & 1,64 & 0,50 & 2,11 & 3,75 \\
\hline 5 & Nederburg (standard) & cabernet & $-0,87$ & 1,67 & 1,33 & 1,50 & 3,17 \\
\hline 6 & Nederburg Edelrood & red blends & $-0,77$ & 1,82 & 1,11 & 2,15 & 3,97 \\
\hline 7 & Welgemeend & red blends & $-0,74$ & 1,85 & 0,95 & 2,00 & 3,85 \\
\hline 8 & Kleine Zalze & merlot & $-0,71$ & 1,92 & 0,77 & 1,58 & 3,50 \\
\hline 9 & Bilton & merlot & $-0,71$ & 1,92 & 1,29 & 2,10 & 4,02 \\
\hline
\end{tabular}

BRANDS WITH HIGH FUNCTIONAL VALUES

All functional brand effects are positive - all symbolic brand effects are negative.

\begin{tabular}{|c|c|c|c|c|c|c|c|}
\hline 1 & Raka & red blends & 0,63 & 3,22 & $-0,62$ & 0,43 & 3,65 \\
\hline 2 & Graham Beck & sauvignon blanc & 0,66 & 2,76 & $-0,66$ & 0,50 & 3,26 \\
\hline 3 & Eikendal & cabernet & 0,68 & 3,21 & $-0,64$ & 0,36 & 3,57 \\
\hline 4 & Diemesfontein & shiraz & 0,70 & 3,41 & $-0,66$ & 0,26 & 3,67 \\
\hline 5 & Bon Courage & sauvignon blanc & 0,75 & 2,85 & $-1,34$ & $-0,30$ & 2,55 \\
\hline 6 & Hazendal & chenin blanc & 0,79 & 3,45 & $-0,84$ & $-0,18$ & 3,27 \\
\hline 7 & Nederberg Private Bin & cabernet & 0,80 & 3,33 & $-0,75$ & 0,25 & 3,59 \\
\hline 8 & Delheim & pinotage & 0,80 & 3,36 & $-0,73$ & 0,29 & 3,65 \\
\hline 9 & Glen Carlou Tortoise Hill & red blends & 0,86 & 3,45 & $-0,90$ & 0,13 & 3,58 \\
\hline 10 & Glen Carlou Grand Classique & red blends & 0,86 & 3,45 & $-0,90$ & 0,08 & 3,52 \\
\hline 11 & Mooiplaas & sauvignon blanc & 0,87 & 2,97 & $-0,89$ & 0,16 & 3,13 \\
\hline 12 & Stellenzicht & shiraz & 0,90 & 3,61 & $-0,57$ & 0,36 & 3,97 \\
\hline 13 & Moreson & pinotage & 1,00 & 3,56 & $-0,89$ & 0,16 & 3,72 \\
\hline 14 & Vergelegen $V$ & red blends & 1,01 & 3,60 & $-0,53$ & 0,85 & 4,45 \\
\hline 15 & Vergelegen Mill Race & red blends & 1,01 & 3,60 & $-0,53$ & 0,32 & 3,92 \\
\hline 16 & Morganhof straight reds & red blends & 1,02 & 3,61 & $-0,63$ & 0,22 & 3,83 \\
\hline 17 & Morganhof Premier Selection & red blends & 1,02 & 3,61 & $-0,63$ & 0,54 & 4,15 \\
\hline 18 & Avontuur & chardonnay & 1,04 & 3,32 & $-0,80$ & 0,16 & 3,48 \\
\hline 19 & Amani & chardonnay & 1,08 & 3,36 & $-0,60$ & 0,35 & 3,72 \\
\hline 20 & Rust en Vrede & red blends & 1,16 & 3,75 & $-0,73$ & 0,43 & 4,18 \\
\hline 21 & Springfield & sauvignon blanc & 1,24 & 3,34 & $-0,89$ & 0,27 & 3,60 \\
\hline 22 & Ernie Els Wines & red blends & 1,35 & 3,94 & $-0,87$ & 0,54 & 4,48 \\
\hline 23 & Cape Point Vineyards & sauvignon blanc & 1,38 & 3,48 & $-0,73$ & 0,43 & 3,90 \\
\hline 24 & Mulderbosch Barrel Fermented, & chardonnay & 1,55 & 3,83 & $-1,14$ & $-0,03$ & 3,79 \\
\hline 25 & Jordan Cobblers Hill & red blends & 1,60 & 4,19 & $-0,73$ & 0,27 & 4,45 \\
\hline 26 & Kanu Limited Release Wooded & chenin blanc & 1,72 & 4,39 & $-1,02$ & $-0,35$ & 4,04 \\
\hline
\end{tabular}




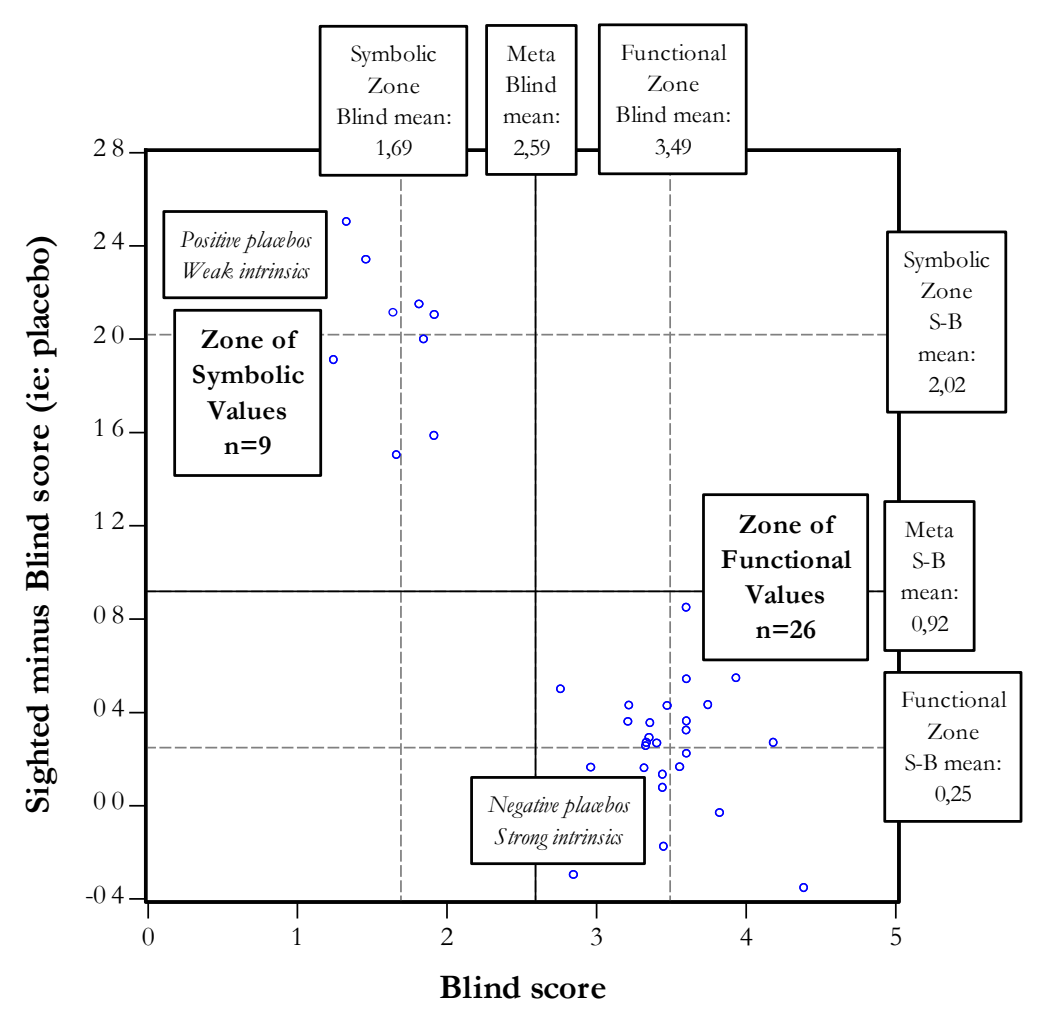

Figure 2: The distribution of zones of symbolic and functional value within a sub-set of brands with both functional and symbolic effects. The smaller Zone of Symbolic Values is characterised by weak intrinsic (-ve functional $\mathrm{b}_{2}$ 's) and strong placebos (+ve symbolic $\mathrm{b}_{2}$ 's); while the second, larger Zone of Functional Values presents the opposite: a span of negative placebos (-ve symbolic $\mathrm{b}_{2}$ 's) coupled with strong intrinsics (+ve functional $\mathrm{b}_{2}$ 's).

Stand-out exemplars appear with their respective predicted blind score and placebo differential in parenthesis: Jordan Cobblers Hill (4,19, 0,27), Ernie Els Wines (3,94, 0,54), Morganhof Premier Selection (3,61, $0,54)$, Rust en Vrede $(3,75,0,43)$, and Vergelegen $V$ $(3,60,0,85)$. (Note: respective wine prices are also factored into the placebo computation.) What we observe here, then, is a sub-set of placebo-symbolic brands imbued with top-quality production-driven values; a finding consistent with the typology presented by Mowle and Merrilees (2005).

Between these clusters there appears to be no middle ground, a finding made all the more remarkable since the weight of all blind scores appears to fall in this noman's land (across the entire dataset, the mean blind score is 2,59 , its standard deviation: 0,92 .) Thus for this class of brand forms we can tentatively conclude that brands appear to differentiate according to their underpinning values: distinctively, possessing either symbolic or functional values, but not both. In this study, these two brand clusters appear to situate one standard deviation left and right of the broader intrinsic mean $(2,59)$.

While these two brand clusters differentiate along the lines of their symbolic and functional values; with respect to sighted appreciation this brand-class evinces no such statistical variation; the sighted Platter scores are seemingly uniform across the sample. Consequently, from the observable perspective of "normal" wine consumption, these two clusters lie submerged from view, all wines appearing to "taste the same". Such is the placebo effect.

An analysis of these two clusters suggests a relationship that for placebos runs along the following lines: the less likely the expected outcome, the greater the degree of faith (and/or marketing input) required to ensure its eventuality. The significance of this relationship is twofold: firstly, that extrinsic cues can muster such powers of persuasion, and secondly, that the brain is so hardwired as to be receptive and capable of such leaps of faith. Where in the instance of this research, placebo-like cues can almost triple the experienced pleasure derived from a product's intrinsic utility (from 1,3 blind stars to 3,83 sighted), we are observing here something close to brainwashing. While the naïve, if not sometimes cynical, market deployment of symbolic cues might to some constitute "effective advertising" at worst they amount to plain propaganda.

While we can now see how symbolic and functional brand values cluster on either tail of the blind and sighted-to-blind normal distributions, a further question addressed by this study is what brand-type, if any, occupies the middle ground between these two clusters? Remarkably perhaps, between these two sub-types lies a central cluster made up of the remaining 37 symbolic brands identified in this study. These are placebo effects that failed to qualify as functional brands. While the intrinsic scores of this cluster are consequently not statistically consistent over time, we can impute their mean averages using WINE magazine data. In 
parenthesis, this sample's respective blind, sighted-toblind and sighted mean and standard deviations are: $(2,55,0,42),(1,09,0,75)$ and $(3,66,0,67)$.

7. Costanigro et al., (2007) observe that high levels of heterogeneity within the wine product class make pooled-sample analysis inappropriate. But is this so here? So as to compare the pooled versus the varietalby-varietal styles of hedonic analysis, this chapter concludes with two meta-models detailing the functional and symbolic brand effects across the entire dataset - see Table 14. Together with the white blend varietal, the dummy trap is avoided using the same vintage price and brand comparators employed earlier. Out of a total meta-sample of 343 brand candidates, the pooled analysis identifies 155 and 63 functional and symbolic brand effects, respectively. This proportion accords with the 148 and 72 functional and symbolic brand effects identified in the varietal-by-varietal analysis. (Of those identified within the pooled sample, the top thirty functional and symbolic brand effects are depicted in Table 15.) Certain wines are identified as common to both tables, and, in order of intrinsic merit, these are: Cape Point Vineyards, Ernie Els, Hamilton Russell, Rustenberg, Rupert \& Rothschild, Vergelegen, Kanonkop, Thelema, Rijks, Jordan and Rust en Vrede, (all functional brands) - and Cabrière, Welgemeend, Raats, Bouchard Finlayson, Beaumont, Cordoba and Meerlust (all symbolic). Again, however, there are a number that do not. Notably absent from the symbolic list is Nederburg - the biggest volume producer featured in this study. In the main this study finds the output from these two meta-models less satisfactory than the output already derived, and from this brief "segmented-to-pool" analysis concur with the views of Costanigro et al, (2007).

Table 14: Estimated regression models explaining blind and sighted minus blind wine assessments for the entire dataset. Model variables appear (with their respective coefficients and significant t-stat figures in parenthesis) in the sequence: constant, vintage, cultivar, price, and brand. Each variable is sorted in order of statistical significance.

$$
\begin{gathered}
\text { All Brands - Entire Dataset } \\
\text { Blind: Adj } R^{2}: 17,06 \%, F: 5,63(p=0,0000, \\
n=8225
\end{gathered}
$$

Statistically significant brand effects: $155 / 343$
All Brands - Entire Dataset

Sighted - Blind: Adj $R^{2}: 7,40 \%, F: 2,79$

$$
(p=0,0000 \text {, }
$$

\begin{tabular}{|c|c|}
\hline & \\
\hline Constant: $(2,05,32,59)$. & Constant: $(0,70,10,50)$. \\
\hline $\begin{array}{l}\text { Vintage: Yr } 2006(0,27,5,16) ; \text { Yr } 2005(0,20,4,74) ; \text { Yr } 1998(0,16,3,45) ; \text { Yr } 2007(0,21,2,69) ; \text { Yr } \\
1999(0,06,1,44) \text {; Yr } 2003(0,05,1,43) ; \text { Yr } 1995(0,45,1,36) ; \text { Yr } 1997(0,07,1,04) ; \text { Yr } 2000(0,01,0,29) \text {; } \\
\text { Yr } 2002(0,01,0,24) \text {; Yr } 2004(0,00,0,10) ; \text { Yr } 1996(-0,06,-0,36) .\end{array}$ & $\begin{array}{l}\text { Vintage: Yr } 2002(0,00,0,06) ; \text { Yr } 1996(-0,03,- \\
0,16) ; \text { Yr } 2004(-0,01,-0,28) ; \text { Yr } 2003(-0,02,-0,66) \text {; } \\
\text { Yr } 2000(-0,03,-0,77) ; \text { Yr } 2007(-0,10,-1,20) \text {; Yr } \\
1995(-0,52,-1,53) \text {; Yr } 1997(-0,17,-2,42) ; \text { Yr } 1999 \\
(-0,14,-3,25) ; \text { Yr } 2006(-0,19,-3,43) ; \text { Yr } 1998(- \\
0,17,-3,44) ; \text { Yr } 2005(-0,19,-4,34) .\end{array}$ \\
\hline $\begin{array}{l}\text { Cultivar: Shiraz }(0,34,5,70) \text {; Red Blend }(0,25,4,38) \text {; Cabernet }(0,23,3,84) \text {; Pinotage }(0,18,2,91) \text {; } \\
\text { Merlot }(0,15,2,48) \text {; Pinot Noir }(0,10,1,14) \text {; Chenin Blanc }(0,03,0,47) \text {; Chardonnay }(-0,02,-0,40) \text {; } \\
\text { Sauvignon Blanc }(-0,10,-1,72) \text {. }\end{array}$ & $\begin{array}{l}\text { Cultivar: Chardonnay }(0,38,6,35) \text {; Sauvignon } \\
\text { Blanc }(0,36,6,03) \text {; Cabernet }(0,32,5,08) \text {; Shiraz } \\
(0,29,4,76) \text {; Merlot }(0,28,4,29) \text {; Pinotage }(0,27 \text {, } \\
4,18) \text {; Red Blend }(0,22,3,69) \text {; Pinot Noir }(0,19 \text {, } \\
2,02) \text {; Chenin Blanc }(0,11,1,59) \text {. }\end{array}$ \\
\hline Partial Functional Brand Effects: Vergelegen $(1,08,10,01)$; Raka $(1,69,9,46)$; Thel & Price: Ratio $(0.0001,0.58)$. \\
\hline
\end{tabular}$$
n=8225
$$

Statistically significant brand effects:

$63 / 343$ 
Jordan (0,95, 8,86); Cape Point Vineyards (1,67, 8,57); Fleur du Cap (0,74, 7,43); De Trafford $(0,87$, $7,43)$; Rustenberg $(1,21,7,40)$; Spice Route $(0,97,7,16)$; Cedarburg $(0,80,6,91)$; Springfield $(1,01$, 6,81); Simonsig $(0,66,6,67)$; Boschendal $(0,71,6,67)$; Neil Ellis $(0,74,6,49)$; L'Avenir $(0,78,6,47)$; Kanonkop (1,04, 6,36); Mulderbosch $(0,81,6,33)$; Hamil-ton Russell $(1,30,6,26)$; Tokara/Zondernaam $(1,01,6,16)$; Glen Carlou $(0,75,6,01)$; Saxenburg $(0,76,5,96)$; Rijks $(0,96,5,95)$; Flagstone $(0,61$, $5,88)$; Ernie Els $(1,48,5,85)$; Kanu Wines $(0,64,5,79)$; Fairview $(0,60,5,79)$; Steen-berg $(0,67,5,69)$; Morgenhof $(0,75,5,64)$; Cape Chamonix $(0,81,5,61)$; Spier $(0,62,5,53)$; Rust en Vrede $(0,91,5,37)$; Hartenberg (0,69, 5,22); Sadie Family (1,26, 5,19); Rupert \& Rothschild (1,12, 5,15); Avontuur $(0,64$, 5,14); Graham Beck $(0,57,5,09)$; Groote Post $(0,63,4,99)$; Longridge $(0,83,4,98)$; Boekenhoutskloof $(0,84,4,92)$; Coleraine $(1,14,4,88)$; Sterhuis $(1,13,4,81)$; Rudera $(1,05,4,81)$; Kumkani $(0,70,4,73)$; Warwick $(0,65,4,68)$; Diemersfontein $(0,68,4,58)$; Newton Johnson $(0,73,4,45)$; Graceland $(0,96$, 4,39); Devon Hill (0,82, 4,31); Laibach (0,55, 4,26); Eikendal $(0,50,4,26)$; Yonder Hill $(0,97,4,17)$; Groot Constantia (0,48, 4,13); Buitenverwachting $(0,56,4,08)$; Avondale $(0,57,4,05)$; Delheim $(0,47$, 4,03); Waterford $(0,67,4,02)$; Mooiplaas $(0,76,3,99)$; Anura $(0,69,3,92)$; Plaisir de Merle $(0,59,3,84)$ Constantia Uitsig $(0,66,3,79)$; Clos Malverne $(0,48,3,75)$; Overgaauw $(0,58,3,69)$; Beyerskloof $(0,62$, $3,69)$; Nitida $(0,53,3,67)$; Post House $(0,71,3,67)$; De Toren $(0,98,3,66)$; Amani $(0,62,3,62)$; Stony Brook $(0,50,3,54)$; Delaire $(0,57,3,52)$; Bon Courage $(0,46,3,52)$; La Cave $(0,69,3,48)$; Zorgvliet $(0,69,3,48)$; Bellingham $(0,42,3,43)$; Rickety Bridge $(0,62,3,42)$; Stellenzicht $(0,41,3,39)$; Môreson $(0,45,3,38)$; Viljoens-drift $(0,45,3,38)$; Havana Hills $(0,54,3,38)$; Saronsberg $(0,79,3,37)$; Remhoogte $(0,72,3,32)$; Klein Constantia $(0,43,3,31)$; Boland Kelder $(0,40,3,29)$; Cathedral Cellar $(0,61,3,13)$; Vil-liera $(0,32,3,12)$; De Grendel $(0,83,3,12)$; Radford Dale $(0,86,3,06)$; Blue Creek $(0,91,3,05)$; Neethlingshof $(0,40,2,97)$; Goats Do Roam $(0,54,2,90)$; Bellevue $(0,71,2,90)$; Grangehurst $(0,61$, $2,89)$; Brampton $(0,49,2,88)$; Fort Simon $(0,39,2,88)$; La Motte $(0,44,2,81)$; Slaley $(0,56,2,80)$; Veenwouden $(0,58,2,76)$; Manley $(0,77,2,76)$; Genesis $(0,56,2,73)$; Bartho Eksteen $(0,77,2,73)$; Ken Forrester $(0,38,2,73)$; Hermanus-pietersfontein $(0,86,2,72)$; Grande Provence $(0,86,2,71)$; Quoin Rock $(0,61,2,69)$; Guardian Peak $(0,53,2,67)$; Black Rock $(0,91,2,66)$; Vergenoegd $(0,40,2,65)$; Jean Daneel $(0,59,2,60)$; Oak Valley Wines $(0,77 ; 2,60)$; Woolworths $(0,23,2,57)$; Koelfontein $(0,87,2,55)$; Land's End $(0,86,2,50)$; Uva Mira $(0,74 ; 2,50)$; Sentinel $(0,41,2,48)$; Paul Cluver $(0,46,2,47)$; Whalehaven $(0,57,2,43)$; Hidden Valley $(0,57,2,43)$; Asara $(0,37,2,41)$; Meinert $(0,64,2,40)$; Durbanville Hills (0,31, 2,39); Lomond (0,67, 2,39); Mont Destin (0,56, 2,38); Lanzerac $(0,38,2,35)$; Cloof $(0,35$, 2,31); Compagnies Post (0,78; 2,28); Tukulu (0,61, 2,27); Meerlust $(0,36,2,25)$; Le Riche $(0,48,2,25)$; Vrede En Lust $(0,77,2,23)$; Sumaridge $(0,34,2,15)$; De Wetshof $(0,36,2,14)$; Kleine Zalze $(0,24,2,13)$; Ridgeback (0,50, 2,13); Pulpit Rock (0,59, 2,09); Groenekloof $(0,71,2,08)$; Marklew $(0,57,2,05)$; Verdun $(0,61,2,03)$; Backsberg $(0,28,2,00)$; Savanha $(0,50,1,96)$; Boplaas $(-0,41,-2,04)$; Jon-kheer $(-0,42$, -2,06); Hildenbrand (-0,55, -2,08); Stellendrift (-0,59, -2,09); Goudini (-0,44, -2,14); Goue Vallei $(-0,47,-2,16)$; Franschhoek Vineyards $(-0,61,-2,29)$; Van Loveren $(-0,34,-2,40)$; Bovlei $(-0,42,-2,42)$; Helderkruin $(-0,66,-2,47)$; Cabrière $(-0,87,-2,49)$, Ivory Creek $(-0,67,-2,74)$; Louiesenhof $(-1,09$, $-3,17)$; Porterville Wines $(-0,65,-3,17)$; Rooiberg $(-0,55,-3,53)$; Ashton Winery $(-0,95,-3,56)$; Lutzville $(-0,85,-3,79)$
Partial Symbolic Brand Effects: Bouchard Finlayson $(0,76,5,39)$; Beaumont $(0,67,5,01)$; Cabrière $(1,66,4,57)$; Zonnebloem $(0,57,4,08)$; Goede Hoop $(0,70,3,84)$; Onxy (Darling Cellars) $(0,75,3,53) ; \quad$ Welgemeend $(0,91,3,26)$;

Onderkloof $(0,90,2,94)$; Cordoba $(0,51,2,83)$; Meerlust $(0,47,2,78)$; Camberley $(0,70,2,76)$; Raats Family Wines $(0,89,2,68)$; Akkerdal $(0,67$, $2,66)$; Kaapzicht $(0,33,2,65)$; Mischa $(0,62,2,65)$; Hoopenburg $(0,43,2,65)$; Boschkloof $(0,68,2,59)$; Signal Hill $(0,62,2,54)$; Meerendal $(0,50,2,47)$; Boplaas $(0,50,2,44)$; De Waal $(0,60,2,29)$; Zevenwacht $(0,32,2,28)$; Linton Park $(0,55,2,28)$;

Overgaauw $(0,36,2,20)$; Grangehurst $(0,48,2,19)$; Talana Hill $(0,72,2,18)$; Fryer's Cove $(1,34,2,18)$; Southern Right $(0,47,2,16)$; Veenwouden $(0,48$, 2,16); Durbanville Hills $(0,28,2,07)$; Le Bonheur $(0,39,2,06)$; Vriesenhof $(0,35,2,03)$; La Bri $(0,52$, $1,99)$; Le Riche $(0,44,1,99)$; Diemersdal $(0,26$, 1,97); Uitkyk $(0,37,1,97)$; Lindiwe $(-0,72,-2,03)$ Wellington Cellar (-0,50, -2,05); Swartland Winery $(-0,30,-2,10)$; Rawsons $(-0,75,-2,11)$; Jordan $(-0,24,-2,11)$; Mellasat $(-0,59,-2,12)$; Car-douw $(-0,65,-2,12)$; Laibach $(-0,29,-2,17)$; Du Toitskloof $(-0,37,-2,26)$; Cederberg $(-0,30,-2,50)$; Groote Post $(-0,33,-2,54)$; Cape Haven $(-0,90,-2,54)$; Bon Courage $(-0,35,-2,55)$; Coleraine $(-0,63,-2,59)$; Simonsig $(-0,27,-2,65)$; Pulpit Rock $(-0,77,-2,66)$; Groot Eiland $(-0,80,-3,05)$; Graceland $(-0,70$, $-3,12)$; Devon Hill $(-0,62,-3,15)$; Edenhof $(-1,13$, $-3,17)$; Rijks $(-0,56,-3,37)$; Sentinel $(-0,60,-3,56)$; Boland Kelder $(-0,45,-3,57)$; Cape Point Vineyards $(-0,73,-3,63)$; Avontuur $(-0,54,-4,19)$; La Cave $(-0,96,-4,67)$; Raka $(-1,41,-7,62)$.

Table 15: The top 30 brand effects derived from the entire-data-set-model: identified for blind and sighted-to-blind assessments. The cited brands present without cultivar controls and appear with their respective functional and symbolic brand effect $\left(b_{2}\right)$ in parenthesis. Predicted intrinsic and placebo scores are fitted values and should be noted in relation to the blind and sighted-to-blind score averages of 2,59 and 0,92, respectively. Italicised brands also feature in the Top 30 cultivarspecific brand listing in Table 12 .

\begin{tabular}{c|c|c|c|c}
\hline \multicolumn{2}{c}{ BLIND MODEL } & \multicolumn{2}{c}{ SIGHTED MINUS BLIND MODEL } \\
\hline \multicolumn{2}{c|}{ Brand and effect size $\left(b_{2}\right)$} & $\begin{array}{c}\text { Intrinsic } \\
\text { merit }\end{array}$ & Brand and effect size $\left(b_{2}\right)$ & $\begin{array}{c}\text { Size of Placebo } \\
\text { (S-B difference) }\end{array}$ \\
\hline 1 & Raka $(1,69)$ & 3,75 & Cabrière $(1,66)$ & 2,35 \\
\hline 2 & Cape Point Vineyards $(1,67)$ & 3,72 & Fryer's Cove $(1,34)$ & 2,04 \\
\hline 3 & Ernie Els Wines $(1,48)$ & 3,54 & Welgemeend $(0,91)$ & 1,60 \\
\hline 4 & Hamilton Russell $(1,30)$ & 3,36 & Onderkloof $(0,90)$ & 1,60 \\
\hline 5 & The Sadie Family $(1,26)$ & 3,32 & Raats $(0,89)$ & 1,59 \\
\hline 6 & Rustenberg $(1,21)$ & 3,27 & Bouchard Finlayson $(0,76)$ & 1,46 \\
\hline 7 & Coleraine $(1,14)$ & 3,20 & Onxy Darling Cellars $(0,75)$ & 1,42 \\
\hline 8 & Sterhuis $(1,13)$ & 3,18 & Talana Hill $(0,72)$ & 1,40 \\
\hline 9 & Rupert \& Rothschild $(1,12)$ & 3,18 & Goede Hoop $(0,70)$ & 1,39 \\
\hline 10 & Vergelegen $(1,08)$ & 3,13 & Camberley $(0,70)$ & 1,38 \\
\hline 11 & Rudera $(1,05)$ & 3,11 & Boschkloof $(0,68)$ & 1,37 \\
\hline 12 & Kanonkop $(1,04)$ & 3,10 & Akkerdal $(0,67)$ & 1,36 \\
\hline 13 & Springfield $(1,01)$ & 3,07 & Beaumont $(0,67)$ & 1,34 \\
\hline 14 & Thelema $(1,01)$ & 3,06 & Mischa $(0,62)$ & 1,32 \\
\hline 15 & Tokara / Zondernaam $(1,01)$ & 3,06 & Signal Hill $(0,62)$ & 1,31 \\
\hline 16 & De Toren $(0,98)$ & 3,03 & De Waal $(0,60)$ & 1,30 \\
\hline 17 & Yonder Hill Winery $(0,97)$ & 3,03 & Zonnebloem $(0,57)$ & \\
\hline
\end{tabular}




\begin{tabular}{c|c|c|c|c}
\hline 18 & Spice Route $(0,97)$ & 3,02 & Linton Park $(0,55)$ & 1,30 \\
\hline 19 & Graceland $(0,96)$ & 3,01 & La Bri $(0,52)$ & 1,30 \\
\hline 20 & Rijks $(0,96)$ & 3,01 & Cordoba $(0,51)$ & 1,29 \\
\hline 21 & Jordan $(0,96)$ & 3,01 & Boplaas $(0,50)$ & 1,26 \\
\hline 22 & Black Rock $(0,91)$ & 2,97 & Meerendal $(0,50)$ & 1,25 \\
\hline 23 & Rust en Vrede $(0,91)$ & 2,97 & Grangehurst $(0,48)$ & 1,24 \\
\hline 24 & Blue Creek $(0,91)$ & 2,96 & Veenwouden $(0,48)$ & 1,22 \\
\hline 25 & Koelfontein $(0,87)$ & 2,93 & Southern Right $(0,47)$ & 1,22 \\
\hline 26 & De Trafford $(0,87)$ & 2,92 & Meerlust $(0,47)$ & 1,21 \\
\hline 27 & Hermanuspietersfontein $(0,86)$ & 2,92 & Le Riche $(0,44)$ & 1,20 \\
\hline 28 & Grande Provence $(0,86)$ & 2,91 & Hoopenburg $(0,44)$ & 1,20 \\
\hline 29 & Land's End $(0,86)$ & 2,91 & Le Bonheur $(0,39)$ & 1,19 \\
\hline 30 & Radford Dale $(0,86)$ & 2,91 & Uitkyk $(0,37)$ & 1,18 \\
\hline
\end{tabular}

\section{Conclusion}

\section{"Marketing and advertising are not innovations of modern civilization, they are deeply biological functions."'}

(Montague, 2006: 214).

Through the deployment of blind and sighted versions of hedonic quality, this study deems placebos to be symbolic brands and so seeks to identify these and their functional equivalents within the context of South African wine brands. This conceptualisation is in line with much of the literature that seeks to interpret extrinsic cues as non-medical placebos (see Plassmann et al., 2008) and which, to date, has identified price as one of the key moderators of a wine's intrinsic merit.

In this paper the brand construct is identified as an additional extrinsic cue-effect. Through empirical analysis it is revealed how certain winery reputations impact consistently on the sighted-to-blind quality differential, presenting as placebo effects; whilst others do not. (In so doing, vintage and price-effects are also noted.) This study reasons that these placebos are predicated on some prior knowledge or expectancy of consistent intrinsic quality, and thus functional and symbolic brands are statistically identified, respectively. Working from a database containing over 8000 sampled wines, we observe the higher proportion of functional-to-symbolic brands - both within a varietal-by-varietal and a pooled-sample style of analysis (148 to 72 versus 155 to 63 , respectively). Interpreted as an evolutionary process, this asymmetric distribution appears to make sense. Not all functional brands spawn placebos. Inspection of the functional and symbolic models suggests a clustering effect, with positive and negative brand effects $\left(b_{2}\right)$ distributed in bi-polar fashion. Negative brands effects can be indicative of wines that are not "firing" appropriately, either because of a lack of quality (in the case of functional brands) - or a lack marketing (in the case of symbolic brands).

This study goes further to consider the 35 brands that present simultaneously as both functional and symbolic brands effects. These particular brands possess elements of both (1) intrinsic consistency - a requirement when interpreting brand equity as a signalling phenomenon, (see Erdem and Swait, 1998), and (2) placebo - as proxied by a consistent sighted-to-blind taste differential. With these 35 brands decomposing into two distinctive zones clustering is again observed. The smaller Zone of Symbolic Values $(n=9)$ is characterised by weak intrinsics (-ve functional $b_{2}$ 's) and strong placebos (+ve symbolic $b_{2}$ 's); while the second, larger Zone of Functional Values $(n=26)$ presents the opposite: a span of weak placebos (-ve symbolic $b_{2}$ 's) coupled with strong intrinsics (+ve functional $\mathrm{b}_{2}$ 's).

By mapping these two zones relative to their intrinsic blind to sighted-minus-blind scores, a tentative architecture of these brand-forms emerges. Distinctively, within this class of simultaneously symbolic and functional brands, no brands appear to occupy the middle ground between these two zones, each located approximately one standard deviation left and right of the mean intrinsic score of the meta-sample.

We extend the arguments of Montague (2006) to speculate that symbolic brands are neurological constructs that in time emerge as placebos from their functional antecedents. Our understanding of these neurological processes is still relatively crude and we remain uncertain as to how the brain enables the functional-to-symbolic-cue transition. This notwithstanding, the observed bi-polar distribution of these respective brand forms appears consistent with much of what evolutionary psychologists and neuroscientists currently suspect as the manner in which symbolic effects develop. The findings of this research go some way in further characterizing a marketing typology for brands, and appear consistent with the literature on non-medical placebo effects and product attributes.

\section{Further research}

Within the discipline of wine marketing, and marketing in general, some effort is required to further refine the constituent characteristics of the two brand zones herein identified, inter-alia, in terms of their symbolic and functional value markers. More so, as our understanding of brand morphology develops, so too must the depth of our quality-based datasets. While this eight-year database has served as a fertile statistical source, it remains to be expanded. Given time, further analysis will reveal the rate 
and conditions under which symbolic brands mutate from their functional underpinnings to become placebos. With sufficient historical data we can, for example, imagine an empirical study detailing the nature and rate in which certain brand characteristics evolve from one time period to the next. Such a study would provide a substantive contribution to the existing literature.

An additional avenue of potential research might be an investigation in to why certain consumers engage in the practice of buying alternative competing brands. Within this "brand-churn" phenomenon one might interrogate the constituent characteristics of these more marginal brands. More so, one might also investigate the type of consumer and their motivations that under-pin the purchase of "change of pace" brands (see Jarvis and Goodman, 2005); bought occasionally or simply as a "once off". What is it, within the psychology of these consumers, that provokes this brand "diversification" strategy - and under what conditions may such levels of "promiscuity" prevail?

Commerce-specific observations aside, further enquiry into the neurology of how we respond to general hedonic stimuli will clarify the extent to which our distinctive two-zone model mapping the functional to symbolic relationship applies across discipline boundaries. This notwithstanding, we observe that the non-medical version of the placebo effect should be interpreted not merely as a commercial heuristic. At a fundamental human level, it forms the basis of both bias and prejudice, belief and faith, and is a major mediator of the human condition.

\section{References}

Bagozzi, R.P., Gopinath, M. \& Nyer, P.U. 1999. 'The role of emotions in marketing', Journal of the Academy of Marketing Science, 27(2): 184-206.

Berns, G.S. 2005. 'Price, placebo, and the brain', Journal of Marketing Research, 42 (November): 399-400.

Bhat, S. \& Reddy, S.K. 1998. 'Symbolic and functional positioning of brands', Journal of Consumer Marketing, 15(1): 32-43.

Boom, C. (Ed.). 2006. SA wine industry directory 2006/7. 8th Edition. Cape Town: Wineland Publications.

Borsook, D. \& Becerra, L. 2005. 'Placebo: From pain and analgesia to preferences and products', Journal of Marketing Research, 42 (November): 394-398.

Carey, V.A. 2005. 'The use of viticultural terroir units for demarcation of geographical indications for wine production in Stellenbosch and surrounds.' Dissertation presented for the Doctoral degree of Agriculture and Forestry Sciences at Stellenbosch University, South Africa, March 2005.

Casini, L., Rungie, C. \& Corsi, A. 2009. 'How loyal are Italian consumers to wine attributes?' Journal of Wine Research, 20(2): 125-142.
Chaney, I.M. 2000. 'External search effort for wine', International Journal of Wine Marketing, 12(2): 5-21.

Chernev, A. 2004. 'Goal-attribute compatibility in consumer choice', Journal of Consumer Psychology, 14(1-2): 141150.

Chitturi, R., Raghunathan, R. \& Mahajan, V. 2007. 'Form versus function: How the intensities of specific emotions evoked in functional versus hedonic trade-offs mediate product preferences', Journal of Marketing Research, 44(November): 702-714.

Chitturi, R., Raghunathan, R. \& Mahajan, V. 2008. 'Delight by design: The role of hedonic versus utilitarian benefits', Journal of Marketing, 72(May): 48-63.

Costanigro, M., McClusky, J.J. \& Mittelhammer, R.C. 2007. 'Segmenting the wine market based on price: hedonic regression when different prices mean different products', Journal of Agricultural Economics, 58(3): 454-466.

Erdem, T. \& Swait, J. 1998. 'Brand equity as a signaling phenomenon', Journal of Consumer Psychology, 7(2): 131157.

Erk, S., Spitzer, M., Wunderlich, A.P., Galley, L. \& Walter, H. 2002. 'Cultural objects modulate reward circuitry', Neuroreport, 13: 2499-2503.

Getz, D. 2000. Explore wine tourism: Management, development and destinations. New York: Cognizant Communication Corporation.

Goodman, S., Lockshin, L., Cohen, E., Fensterseifer, J., Ma, H., d'Hauteville, F., Sirieix, L., Orth, U., Casini, L., Corsi, A., Jaeger, S., Danaher, P., Brodie, R., Olsen, J., Thatch, L. \& Perrouty, J. 2008. 'International comparison of consumer choice for wine: A twelve country comparison'. In Proceedings of the $4^{\text {th }}$ International Conference of the Academy of Wine Business Research, Siena, 17-19 July 2008.

Halstead, L. 2002. 'How do customers select wine? Factors that affect the purchase decision making process in the wine category', Annual Academy of Marketing (June 2002), Nottingham.

Irmak, C., Block, L.G. \& Fitzsimons, G.J. 2005. 'The placebo effect in marketing: Sometimes you just have to want it to work', Journal of Marketing Research, 42 (November): 406-409.

Jarvis, W. \& Goodman, S. 2005. 'Effective marketing of small brands: niche positioning, attribute loyalty and direct marketing', Journal of Product and Brand Management, 14(5): 292-299.

Kamakura, W. A. \& Russell, G. J. 1993. 'Measuring brand value with scanner data', International Journal of Research Marketing, 10: 9-21. 
Kim, W. \& Mauborgne, R. 2005. Blue ocean strategy. Boston: Harvard Business School Press.

Kawabata, H. \& Zeki, S. 2004 'Neural correlates of beauty', Neuron, 91: 1699-1705.

Keller, K. L. 1993. 'Conceptualizing, measuring, and managing customer-based brand equity', Journal of Marketing, 57: 1-22.

Kivetz, R. \& Simonson, I. 2002a. 'Earning the right to indulge: Effort as a determinant of customer preferences towards frequency program rewards', Journal of Marketing Research, 39(May): 155-170.

Kivetz, R. \& Simonson, I. 2002b. 'Self-control for the righteous: Toward a theory of precommitment to indulgence', Journal of Consumer Research, 29(September): 199-217.

Lockshin, L., Rasmussen, M. \& Cleary, F. 2000. 'The nature and roles of the wine brand', Australian and New Zealand Wine Industry Journal, 15(4): 17-24.

McClure, S.M., Li, J., Tomlin, D. Cypert, K.S., Montague, K.M. \& Montague, P.R. 2004. 'Neural correlates of behavioral preference for culturally familiar drinks', Neuron, 44: 379-387.

McDonald, F., Simon, J. \& Eedes, C. 2007. 'Reader Poll 2007', Wine (June): 40-47.

Montague, P. R., Hyman, S.E. \& Cohen, J.D. 2004. 'Computational roles for dopamine in behavioural control', Nature, 431: 760-767.

Montague, R. 2006. Why choose this book? How we make decisions. New York: Dutton Press.

Mowle, J. \& Merrilees, B. 2005. 'A functional and symbolic perspective to branding Australian SME wineries', Journal of Product and Brand Management, 14(4): 220-227.

Oliver, R. 1997. Satisfaction: A behavioral perspective on the consumer. New York: McGraw-Hill.

Plassmann, H., O’Doherty, J., Shiv, B. \& Rangel, A. 2008. 'Marketing actions can modulate neural representations of experienced pleasantness', Proceedings of the National Academy of Sciences, 105(3): 1050-1054.

Ponte, S. \& Ewert, J. 2007. 'South African wine - An industry in ferment'. Tralac Working Paper No 8/2007 (October 2007).

Priilaid, D. 2006. 'Wine's placebo effect: How the extrinsic cues of visual assessment mask the intrinsic quality of South African red wine', International Journal of Wine Marketing 18(1): 17-32.

Priilaid, D. 2007. 'The placebo of place: Terroir effects in the blind and sighted quality assessments of South African varietal wines', Journal of Wine Research, 18(2): 87-105.
Priilaid, D., Feinberg, J., Carter, O. \& Ross, G. 2009. 'Follow the leader: How expert ratings mediate consumer assessments of hedonic quality', South African Journal of Business Management, 40(4): 15-22.

Priilaid, D. \& Van Rensburg, P. 2006. 'Non-linearity in the hedonic pricing of South African red wines', International Journal of Wine Marketing, 18(3): 166-182.

Rao, R.R. 2005. 'The quality of price as a quality cue', Journal of Marketing Research, 42 (November): 401-405.

Robinson, J. (Ed.) 2006. The Oxford companion to wine. 3rd Edition. Oxford: Oxford University Press.

Robinson, J. 2008. 'South African stars, served on a "Platter" , Financial Times. [online] URL: http://www ft.com/cms/s/2/2ff788a2-fc5a-11dc-9229000077b07658.html?nclick_check=1. Accessed 20 July 2009.

Rust, R.T. \& Oliver, R.L. 2000. 'Should we delight the customer?' Journal of the Academy of Marketing Science, 28(1): 86-94.

Seghieri, C., Casini, L. \& Torrisi, F. 2007. 'The wine consumer's behaviour in selected stores of Italian major retailing chains', International Journal of Wine Business Research, 19(2): 139-151.

Shiv, B., Carmon, Z. \& Ariely, D. 2005. 'Placebo effects of marketing actions: Consumers may get what they pay for', Journal of Marketing Research, 42 (November): 383-393.

Siegrist, M. \& Cousin, M. E. 2009. 'Expectations influence sensory experience in a wine tasting', Appetite, 52 (2009): 762-765.

Spawton, T. 1991. 'Marketing and planning for the wine industry', European Journal of Marketing, 24(3): 6-48.

Taplin, I.M. 2006. 'Competitive pressures and strategic repositioning in the Californian premium wine industry', International Journal of Wine Marketing, 18(1): 61-70.

Van Rensburg, P. \& Priilaid, D. 2004. 'An econometric model for identifying value in South African red wine', International Journal of Wine Marketing, 18(1): 53-75.

Van Zyl, P. (Ed.) 2007. John Platter's South African Wine Guide 2000. Cape Town: Injectrade 25. 